What does a satellite campaign do? The use of Momentum in Labour's 2017 General Election Facebook campaign

Tristan Hotham ${ }^{\mathrm{a}}$

${ }^{a}$ Department of Politics, Languages and International Studies, University of Bath, Bath, United Kingdom

Correspondence address - Mr. Tristan Hotham, Department of Politics, Languages and International Studies, University of Bath, Claverton Down, Bath, Somerset, BA2 7AY

Tristan Hotham is a PhD candidate at the University of Bath.

***Working Paper***

Word Count: 15919 


\title{
What does a satellite campaign do? The use of Momentum in Labour's 2017 General Election Facebook campaign
}

\begin{abstract}
Satellite campaigns have been discussed as core parts of parties online campaigns. However, study is needed to understand the specifics of what satellite campaigns are, where they fit and how they are used as part of parties' social media election campaigns. This article comparatively examines Facebook pages across the 2017 general election; Momentum, Labour Party page and Labour leader page information and participation content is comparatively investigated to understand what sets satellite campaigning apart. Findings show that Labour had generated a Facebook approach termed 'Janus-faced campaigning'. Labour was using leader, party and satellite pages with diverse approaches to speak to different audiences, thus presenting different faces of the same party to the public. The party engaged in two core forms of approach. The 'traditional Facebook campaign' via the leader and party page, saw the party using core policy messages, open inclusive rhetoric and a focus on information over participation to campaign to the mass public. This approach was supported by what is termed the 'new methods Facebook campaign'. Here, satellite page Momentum focused equally on participation and information, using novel, partisan and divisive content, large amounts of leadership personalisation and humour, to activate a younger more partisan audience and get them campaigning online and offline. The group treated their online audience as a reservoir of potential offline campaign activism, breaking down the barriers between 'official' and 'virtual members'. This multifaceted approach allowed Labour to engage in different strands of organic communications, campaigning to (and through) different audiences in the most effective manner.
\end{abstract}

\section{Keywords}

Campaigning, political communication, satellite campaigning, Facebook, election campaigns, social media, digital politics 


\section{Introduction}

The influence of external-to party organisations and groups on elections has been of central interest to researchers for decades. Across the role of the media, unions and charity organisations, it has always been clear that elections are not just battles between parties' campaigns, other factors and power-groups have always been at play. Over a decade ago, Edwards posited the notion of 'democratic intermediaries' (2006: 9), a term used to describe non-party organisations important within elections and party campaigns. More recently, with the rise of social media this idea of democratic intermediaries has expanded via what Dommett and Temple call the rise of 'satellite campaigns' on Facebook (2018). Satellite campaigns present a major opportunity for party campaigns, because of the potential for these suborganisations to campaign in a different way or be used for different purposes than official party or leader pages. Thus, the rise of satellite campaigns presents new questions for how parties are campaigning using Facebook, but also how they are campaigning more generally.

Unlike past iterance's of democratic intermediaries which were easier to delineate, modern satellite campaign organisations can be much more diverse. They can be directly linked to a party or feature looser connections, are also capable of merging together Edwards' ideas of preference, information, and interaction intermediaries (2006). This fluidity has meant that party satellite campaigns are not always clearly linkable to parties' campaigns, with these groups often playing upon the differences within their online presence, making the line of distinction of what is a party's online campaign harder to define. At the most problematic end of this phenomenon, we have the rise of clandestine uses of satellite pages, labelled 'clandestine campaigning'; a new burgeoning arena of satellite campaigning seen in third party activity during the 2019 general election (Dommett and Bakir 2020). This is an area that requires further study and updated campaign regulations to control. At the other end we have clearly party associated satellite campaigns, which for this article includes Labour Party campaign group 
Momentum. Overall, satellite campaigns can be utilised and admixed within parties' traditional campaigns or be separate entities, with the rise of 'satellite campaigns' driven directly by the power and influence of social media.

Satellite campaigns matter because we have seen over the last few decades a continued decline in partisanship, a third of voters switched parties between the 2015 and 2017 General Elections (Fieldhouse et al. 2019). Volatility is very high with partisanship and community not as strongly linked as in the past (Putnam 1996). Parties are also claimed to be in decline, with membership low within political and societal organizations, and reduced trust in the leading political and social institutions such as the Government, Parliament or courts (Schudson 1998; Putnam 2000). These issues, within a wider discourse, amount to what has been labelled a growing "democratic deficit" (Seidle, 2004) or even a "crisis of democracy" (Zittel and Fuchs 2007). It is commonly accepted that a major way to reverse this crisis is to increase the level of political participation. Although we have seen British parties grow in membership recently, the general trend of party membership is downwards. Given this situation, as election campaigning is strongly dependent on scarce resources (Margolis et al. 2003; Ward et al. 2008; Anstead and Chadwick 2009), some parties have opened themselves up to citizen participation fostering new ways to become a campaign volunteer (e.g., Gibson and Ward 2000; Hooghe and Vissers 2008; Schweitzer 2011). However, given the low levels of participation content seen from the traditional Facebook campaign, we are potentially seeing this online participation operating via new satellite pages. As Dommett and Temple state;

“...by drawing on the energies of citizens who may not feel sufficiently enthused to join a party, but who may nevertheless share party values, satellite campaigns can provide a wider set of advocates, who may be better placed to articulate their appeal... blurring the lines between models of party membership and affiliation” (2018: 202). 


\section{Conceptualising satellite campaigns}

The enigmatic quality of satellite campaigns and their current lack of conceptual clarity requires analysis. Dommett and Temple, in their article Digital Campaigning: The Rise of Facebook and Satellite Campaigns (2018), posited the role of Momentum and Campaign Together during the 2017 General Election as examples of these 'satellite campaigns' that "represent a distinctive and important shift in campaigning" (2018: 189). Dommett and Temple outline their concept of satellite campaigns as: "Organisations beyond parties were identifying, mobilising and organising citizens to deliver leaflets, canvass voters, and organise on- and offline... It suggests that, in addition to Whiteley and Seyd's categories of the central party campaign, centrally coordinated local campaigns, and purely locally directed campaigns (2003: 638), we can also identify campaigns originating beyond party structures and control—-those termed here 'satellite' campaigns" (2018: 201). However, satellite campaigns are clearly problematic to define, as Dommett and Temple assert "affiliate organisations such as trade

unions, business organisations, and community groups, have long provided additional resources for parties' electoral campaigns" (2018: 195). Given this clear lack of definition between previously identified 'democratic intermediaries' (Edwards 2006) and 'satellite campaigns' (Dommett and Temple 2018), the need for a new label appears unnecessary. However, the need for a new terminology and classification arises because of the way social media is interacting with these third parties.

Dommett and Temple emphasise that "the capacities of digital appear to have altered previous practice" (2018: 195). Social media has altered democratic intermediaries into something different and more powerful, with change pronounced enough that a definitional cleavage is necessary. This definitional shift is warranted because digital platforms have increased the reach and capabilities of democratic intermediaries to campaign. Even small intermediaries have seen their campaign reach and impact vastly improved through social 
media, meaning that many third-party groups now have a central campaign function rather than an intermediary function. As such the essence of what satellite campaigns are and can action, is heavily related to the digital tools they use. Today, satellite campaigns exist across the full range of social networks available. Facebook is examined over other platforms because of its well-defined satellite campaign network, large userbase, wider socio-political-demographic representation and greater capacities for different campaign approaches. Examining Facebook is essential for understanding what satellite campaign organisations are, how they act and what their function is.

Although we know satellite campaigns exist and are an important phenomenon, there is a lack of precision in defining what different satellite campaigns are. Although, Dommett and Temple's contribution to the identification of 'satellite campaigns' on Facebook is important in defining this new campaign dynamic, they fail to adequately conceptualise the differentiated roles satellite campaigns can have. Firstly, Dommett and Temple suggest that satellite campaigns feature the "increasing importance of intermediary, unofficial, organisations beyond parties that facilitate and promote campaigning activities", suggesting that "a campaign can be classed as satellite when vote-seeking activism is primarily driven by intermediary organisations without the control of a party" (Dommett and Temple 2018: 202). In the case of Momentum, a clear example of a satellite campaign, this definition does not fit. This is because Momentum as an organisation is still heavily related to the Labour Party; Labour is the parent organisation, all Momentum members since January 2017 must be Labour Party members, they campaign using Labour platforms such as the Party Conference and feature close links with Labour MP's. As such I would assert Momentum, although clearly a satellite, is still part of the overall Labour Party campaign akin to Progress or other internal group's within Labour. Although the lines of control and connection are inherently ambiguous and blurred, Momentum is still clearly a party-linked satellite campaign. 
Further issues in conceptualisation are also apparent in Dommett and Temple's second example of a satellite campaign; 'Campaign Together'. Campaign Together is a volunteer nonparty affiliated tactical anti-Conservative organisation. Simply defining this group as a satellite campaign akin to Momentum fails to appreciate a core element of satellite campaigning; that some groups have set points of orbit while others do not. This cleavage is vital, as it is important to define the deliberative use of satellite campaigns by parties separately from "satellite" campaigns that provide incidental aid. Campaign Together has no central orbiting point, is not party-linked and is independent, Campaign Together may incidentally help the Labour Party but is not linked with the party. Thus, Campaign Together and Momentum are different entities and need to be conceptualised differently. Dommett and Temple's definition of satellite campaigns fails to address the huge differences seen between these two groups natures, goals and activities.

What is required is a typology of the different categories of satellite campaigns that exist on Facebook using more nuanced descriptors, whilst where pertinent still conceptualising these different groups under the umbrella term of satellite campaigns. This paper consequently creates a more comprehensive typology of different types of satellite campaigns seen via Facebook. Using the example of the Labour Party, Table 1 includes four core differentiated types of party-linked satellite pages found on Facebook. The central dichotomy generated is between official party-linked and indirectly party-linked satellite campaigns based upon relationship to party. Further, the new typology offers a reclassification of non-party affiliated campaigns such as Campaign Together, to definition outside of party-satellite campaigning as incidental campaigns. The central orbiting point, around which party-linked pages are satellite to, is the Labour party and leader pages. As previously asserted these pages are the 'traditional Facebook campaign' the core of parties' campaigns on Facebook and thus the pivot point around which satellites orbit on Facebook. 
Table 1. Conceptualisation of the seven forms of satellite campaign pages seen on Facebook

\begin{tabular}{|c|c|c|c|c|c|c|c|}
\hline \multicolumn{5}{|c|}{ Party satellite campaigns (official party-linked) } & \multirow{2}{*}{$\begin{array}{c}\begin{array}{c}\text { Unofficial satellite } \\
\text { campaigns (indirectly } \\
\text { party-linked) }\end{array} \\
\text { Fan/grassroots pages }\end{array}$} & \multicolumn{2}{|c|}{ Mon-party incidental campaigns (independent) } \\
\hline Type & Party movement & Local pages & Individual MP's pages & $\begin{array}{c}\text { Traditional } \\
\text { democratic } \\
\text { intermediaries }\end{array}$ & & Tactical/turnout/reformist & $\begin{array}{c}\text { Traditional } \\
\text { democratic } \\
\text { intermediaries }\end{array}$ \\
\hline Other Examples & Labour Leave, Blue Labour & $\begin{array}{l}\text { Milton Keynes Labour } \\
\text { Party, Labour South West }\end{array}$ & $\begin{array}{l}\text { John McDonnell, Ben } \\
\text { Bradshaw }\end{array}$ & $\begin{array}{l}\text { Institute for Public } \\
\text { Policy Research }\end{array}$ & $\begin{array}{l}\text { Grime4Corbyn, Jeremy } \\
\text { Corbyn: The People's PM }\end{array}$ & $\begin{array}{l}38 \text { Degrees, Tactical Vote - Stop the } \\
\text { Tories, Rize Up }\end{array}$ & $\begin{array}{l}\text { Save the Children, } \\
\text { Demos }\end{array}$ \\
\hline Example Used & Momentum & Cardiff Central Labour & Rebecca Long-Bailey & Unison & JeremyCorbyn4PM & Campaign Together & $\begin{array}{l}\text { National Education } \\
\text { Union }\end{array}$ \\
\hline Link to Party & Official formal links with party & $\begin{array}{l}\text { Official formal links with } \\
\text { party }\end{array}$ & $\begin{array}{l}\text { Official formal links with } \\
\text { party }\end{array}$ & $\begin{array}{l}\text { Official formal links } \\
\text { with party }\end{array}$ & $\begin{array}{l}\text { Unofficial emotional links } \\
\text { with party }\end{array}$ & $\begin{array}{l}\text { Unofficial, purely tactical links with } \\
\text { party }\end{array}$ & Independent \\
\hline Size (2019) & $\begin{array}{l}\text { 40,000 members, } 250,815 \\
\text { Facebook followers }\end{array}$ & 975 Facebook followers & 10,533 Facebook followers & $\begin{array}{l}\text { 1,377,006 members, } \\
\text { 47,748 Facebook } \\
\text { followers }\end{array}$ & $\begin{array}{l}\text { 328,445 Facebook } \\
\text { followers }\end{array}$ & 3,104 Facebook followers & $\begin{array}{l}\text { 461, } 950 \text { members, } \\
29,000 \text { Facebook } \\
\text { followers }\end{array}$ \\
\hline Facebook Links & Central links are to leader page & $\begin{array}{l}\text { Central links are to party } \\
\text { page }\end{array}$ & $\begin{array}{l}\text { Central links are dependent } \\
\text { on the MP }\end{array}$ & $\begin{array}{l}\text { Central links are with } \\
\text { other democratic } \\
\text { intermediaries }\end{array}$ & $\begin{array}{l}\text { Central links are to other } \\
\text { 'fan' pages }\end{array}$ & $\begin{array}{l}\text { Central links are to other } \\
\text { 'reformist/tactical' pages }\end{array}$ & $\begin{array}{l}\text { Central links are with } \\
\text { other democratic } \\
\text { intermediaries }\end{array}$ \\
\hline Goal & $\begin{array}{l}\text { Support left wing of Labour Party } \\
\text { and Corbyn. Defeat opposition }\end{array}$ & Promote local issues & $\begin{array}{l}\text { Promote the MP and local } \\
\text { issues }\end{array}$ & $\begin{array}{l}\text { Support unionism, } \\
\text { union workers interests } \\
\text { and the Labour party }\end{array}$ & Support Jeremy Corbyn & $\begin{array}{l}\text { Promote progressive candidates, } \\
\text { tactical voting }\end{array}$ & $\begin{array}{l}\text { Support unionism, } \\
\text { union workers interests }\end{array}$ \\
\hline Membership & $\begin{array}{l}\text { Has monetary backing and } \\
\text { membership }\end{array}$ & $\begin{array}{l}\text { Has monetary backing and } \\
\text { membership }\end{array}$ & $\begin{array}{l}\text { Has monetary backing and } \\
\text { membership }\end{array}$ & $\begin{array}{l}\text { Has monetary backing } \\
\text { and membership }\end{array}$ & $\begin{array}{l}\text { Purely online and operated } \\
\text { via donations }\end{array}$ & $\begin{array}{l}\text { Operates via donations but purely } \\
\text { online }\end{array}$ & $\begin{array}{l}\text { Has monetary backing } \\
\text { and membership }\end{array}$ \\
\hline Online or Offline & Can act online and offline & Can act online and offline & Can act online and offline & $\begin{array}{c}\text { Can act online and } \\
\text { offline }\end{array}$ & $\begin{array}{l}\text { Campaigns online, offline } \\
\text { campaigning is incidental }\end{array}$ & $\begin{array}{l}\text { Mainly campaigns online, offline } \\
\text { campaigning is incidental }\end{array}$ & $\begin{array}{l}\text { Can act online and } \\
\text { offline }\end{array}$ \\
\hline Online Presence & $\begin{array}{l}\text { Has its own party apparatus and } \\
\text { online eco-systems like websites }\end{array}$ & $\begin{array}{l}\text { Often has own party } \\
\text { apparatus and online eco- } \\
\text { systems like websites }\end{array}$ & $\begin{array}{c}\text { Uses local networks, often } \\
\text { has online eco-systems like } \\
\text { websites }\end{array}$ & $\begin{array}{l}\text { Has own organisational } \\
\text { apparatus and online } \\
\text { eco-systems like } \\
\text { websites }\end{array}$ & $\begin{array}{l}\text { Does not have its own } \\
\text { party apparatus and only } \\
\text { presence is via social media }\end{array}$ & $\begin{array}{l}\text { May have websites but does not have } \\
\text { its own party apparatus and main } \\
\text { presence is via social media }\end{array}$ & $\begin{array}{l}\text { Has own organisational } \\
\text { apparatus and online } \\
\text { eco-systems like } \\
\text { websites }\end{array}$ \\
\hline Professionalisation & $\begin{array}{c}\text { Features a professionalised paid } \\
\text { core staff, although wider staff } \\
\text { will be voluntary }\end{array}$ & $\begin{array}{l}\text { Features a professionalised } \\
\text { paid core staff, although } \\
\text { wider staff will be voluntary }\end{array}$ & $\begin{array}{l}\text { Features a professionalised } \\
\text { paid core staff, although } \\
\text { wider staff will be voluntary }\end{array}$ & $\begin{array}{l}\text { Features a } \\
\text { professionalised paid } \\
\text { core staff }\end{array}$ & $\begin{array}{c}\text { Un-professionalised, staff } \\
\text { of a small scale and totally } \\
\text { voluntary, content will be } \\
\text { crowd sourced }\end{array}$ & $\begin{array}{l}\text { Features a professional but voluntary } \\
\text { staff }\end{array}$ & $\begin{array}{l}\text { Semi-professionalised, } \\
\text { staff of a small scale }\end{array}$ \\
\hline Content & $\begin{array}{l}\text { Extensively uses bespoke content } \\
\text { created in house, reissues other } \\
\text { page's content, uses humour and } \\
\text { 'internet style' }\end{array}$ & $\begin{array}{l}\text { Some bespoke content, } \\
\text { reissues other page's } \\
\text { content, local focus }\end{array}$ & $\begin{array}{l}\text { Some bespoke content, } \\
\text { reissues other page's } \\
\text { content, may be } \\
\text { personalised, local focus }\end{array}$ & $\begin{array}{l}\text { Uses bespoke content } \\
\text { created in house }\end{array}$ & $\begin{array}{l}\text { Little bespoke content, } \\
\text { reissues other page's } \\
\text { content, uses humour and } \\
\text { 'internet style' }\end{array}$ & $\begin{array}{l}\text { Uses bespoke content created in } \\
\text { house }\end{array}$ & $\begin{array}{l}\text { Some bespoke content } \\
\text { created in house, } \\
\text { reissues other page's } \\
\text { content }\end{array}$ \\
\hline
\end{tabular}


Examining Table 1, firstly, there are party linked official satellite campaigns. The first of these are party movement satellite pages, these often feature an internal political dimension and as such semi-independence but are still formally linked with the mother campaign. Momentum is a perfect example of this, with its links centrally seen to the leader page. Secondarily, there are a huge number of local, county, regional and subnational party groups, often representing local party organisations that campaign during the election. These are centrally linked to the party page and are focussed on local issues. Examples include groups such as Cardiff Labour or Cheltenham Labour. Thirdly, and highly related to local pages, are the hundreds of MP pages that exist on Facebook. For example, every Labour MP has their own Facebook page that campaigns during elections. These pages' link to the party or leader page depending on their internal partypolitical position. Finally, akin to the offline world, there are the online representations of party-linked traditional democratic intermediaries including entities such as unions and think tanks. Unison is an example of this for Labour, with central links to the party page and other Labour-affiliated unions.

As well as official party-linked satellite campaigns, an unofficial party-associated satellite campaign theme is defined. Fan/grassroots pages are not party-linked but are party supporting pages usually run by volunteers. As such one cannot label their impact as incidental as these pages are run explicitly to support a party, however equally they are clearly not part of any official satellite campaign page network. Fan-made pages can utilise a less formal approach and are often interlinked with other fan-made or alternative sources. For example, JeremyCorbyn4PM is interlinked with Corbyn's page as well as the Artist Taxi Driver and Another Angry Voice. The changing political landscape on Facebook has seen these unofficial satellite pages become more influential. Dozens of these pages exist for all the major parties, with their capacities for campaigning leading to many interesting developments in the use of fan pages for what I term 'cluster 
campaigning'. This defines campaigning based upon numerous seemingly independent sources but controlled by a close band of creators. This is important because some of these supposedly unofficial pages are clandestinely being used by parties' campaigns, examples are provided later. In future, the typology of satellite campaigns may need to include some seemingly independent fan pages as a type of party-linked campaigning. This is because of how the lines between party and unofficial satellite campaigns are blurring. Currently, given how fan pages are a relative unknown and need far more study, they are not defined as officially linked.

The final two types of pages shown within Table $\mathbf{1}$ are labelled as non-party incidental campaigns. These groups are not labelled as satellite campaigns because these pages have no specific party of orbit. Instead the term incidental campaign is created as these groups can help certain parties, but this is not their specific aim. For example, Campaign Together promotes 'progressive candidates' tactical voting and as such can help Labour, but the primary focus of the page is to help non-Conservative candidates. Alongside these pages, akin to the offline world, there are also the online representations of unaffiliated traditional democratic intermediaries including entities such as unions, think tanks and charities. As shown via Unison these can explicitly help a party, but other non-political independent examples exist that may only incidentally help a party. The detachment of these incidental campaign groups from satellite campaigns makes defining the role and influence of satellite campaigns much clearer.

Finally, hyper-partisan media organisations and opinion leaders were not included within this typology as these areas are too broad and are more clearly defined within other theoretical areas. Hyper-partisan media organisations such as Skwawkbox and Novara Media are particularly linked with the Corbyn/Labour project. This may lead one to argue they act akin to unofficial satellite fan pages. However, as these groups are primarily alternative media sources, current understandings of hyper-partisan news are better suited 
to explaining their electoral role (Potthast et al., 2017) than the concept of satellite campaigning. Similarly, opinion leaders with social media presences (who have also been termed 'outriders'- see Cohen, 2019) can also be clearly linked to parties. Owen Jones is a clear example, the Guardian journalist and Labour activist campaigned for the Labour Party during the 2017 General Election. These individuals with large Facebook presences may be asserted to be satellites of the Labour Party. However, Jones as well as other individuals such as Aaron Bastani and Ash Sarkar of Novara Media, did not campaign extensively on their own, instead they all campaigned via Momentum. The fact that these 'outriders' engaged in a party-linked satellite campaign speaks to the difference of opinion leaders to satellite campaigns. These individuals appreciate that there is a clear difference between a professionalised organisation used to campaign, and their own individual influence via their communications. As such merging the idea of opinion leaders with satellite campaigning is problematic, as not only would the concept become too large and unwieldy, but also the pre-existing ideas of opinion leadership via Lazarsfeld et al. (1944) explains the role of these individuals better than the idea of satellite campaigning. Although academics and commentators have outlined what satellite campaigns are in the broadest sense, it is not known how they operate or what strategies they use for information. Satellite campaigns have the potential for innovation (Dommett and Temple: 2018), with abilities to adopt internet-culture, divergent viewpoints or ultra-partisan takes on politics.

\section{Studying Labour and Momentum}

Of the new satellite campaign groups seen on Facebook, Momentum stands out as of major value for study because of its self-reported importance within the 2017 Labour Party campaign. Momentum with its $\sim 40,000$ members (2019), boasted of their 
importance to the 2017 Labour campaign. They asserted that more than 100,000 people used their My Nearest Marginal tool during the campaign. While their Facebook videos reached over 23 million views and were watched by 12.7 million unique users (McDowellNaylor 2019). As a grassroots Labour Party movement supportive of Jeremy Corbyn, the rise of Momentum has seen the real-world application of a satellite campaign to an election where social media was central. To understand satellite campaigns role within a wider party Facebook campaign; Momentum (party linked movement page) is examined alongside the Jeremy Corbyn (leader page) and Labour Party page (party page). As shown in Figure 1, satellite campaigns have been a key part of Labour's Facebook presence for half a decade, with the group a clear focus for engagement with Labour's politics, even with the rise of Keir Starmer.

Figure 1. Total like engagement per year by page 2010-2020. Relevant leader page used for each year; Miliband 2010-2015; Corbyn 2016-2019; Starmer $2020(\mathrm{n}=24,390)$

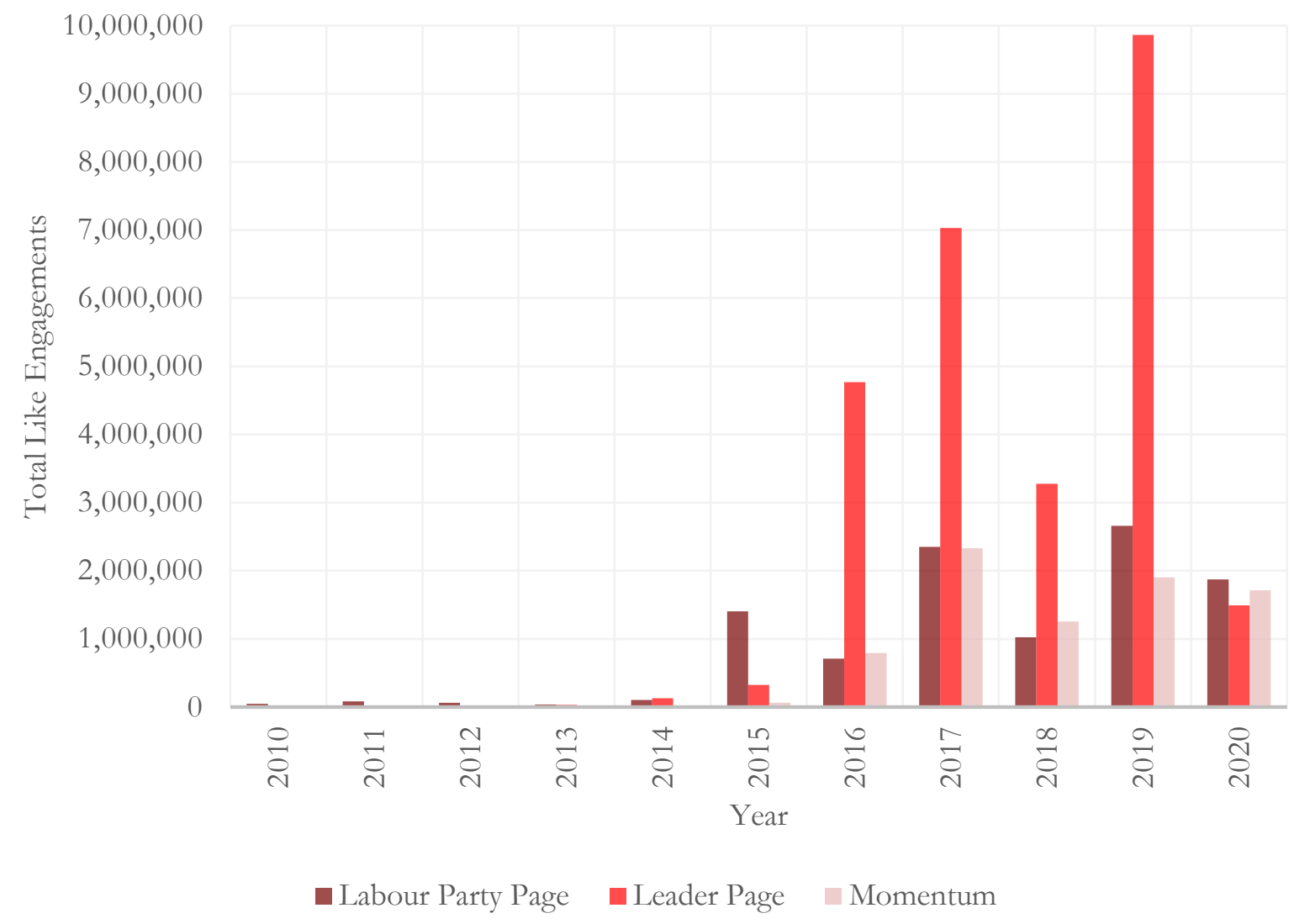




\section{Understanding how satellite campaigns are used. Conceptualising Janus-faced campaigning - the 'traditional' and 'new methods' Facebook campaign}

Parties national campaigns on Facebook have moved beyond the use of party pages as seen in 2010, past the combination of leader and party pages seen in 2015, towards the use of multiple pages all utilising different approaches in 2017. Parties are now harnessing Facebook with great complexity, with campaigns more multi-faceted, nebulous, and hard to discern. The key elements of this new trajectory in campaigning must be defined, with Janus-faced campaigning a definitional term used to describe how parties are now campaigning using Facebook. Janus-faced campaigning centrally defines a tactic that has always been important to parties' campaigns; the sending of different messages to different voter groups using different methods, styles, and approaches. Campaign complexity and multi-faceted approaches are arguably nothing new, for example, leaflets have been heavily localised for decades (Shephard 2016). However, social media in the modern era presents a large cleavage in the capacity of parties to action far more diverse strategies both via targeted and organic communications. Janus-faced campaigning on Facebook is thus defined as a party; using different pages with different approaches to reach different audiences, thus presenting different faces of the same political party to the public.

Janus-faced campaigning describes a powerful campaign dynamic. Through the replication of a national broadcast campaign via the traditional Facebook campaign, parties can influence the mass public. With approach focused on broader topics of public concern, information rather than participation and voting/registration participation content, parties can reach out to the median voter in considered language. Alongside this central core, through the new methods element of Janus-faced campaigning, parties can benefit from novel approaches. Approach can be as broad as the number of satellite pages 
a party has, with approach informed by the nature and audience of each page. For example, Momentum focuses on participation and emotive partisan information, Grime4Corbyn focusses on younger black audiences and cultural/identity politics, while Cardiff Labour focusses on Cardiff infused partisan Labour politics. The new methods campaign gives parties new capacities that the traditional campaign cannot, including a focus on partisan content, participation and novel communications forms. Thus, through both these avenues, Janus-faced campaigning on Facebook gives parties the best of both worlds. Parties are not only able to reap the sociological rewards of more traditional broadcast approaches to campaigning, but also utilise narrowcast targeted approaches. This system operates across both organic communications and targeted advertising, giving parties radical new dimensions of campaign approach. Table 2 outlines the differences between the elements.

Table 2. Outline of traditional and new methods within Janus-faced campaigning

\begin{tabular}{|c|c|c|}
\hline & \multicolumn{2}{|c|}{ Janus-faced campaigning } \\
\hline Theme & Traditional Facebook campaign & New methods campaign \\
\hline Source & $\begin{array}{l}\text { The core pages - party and leader } \\
\text { pages }\end{array}$ & $\begin{array}{l}\text { Satellite pages - party controlled pages or } \\
\text { acquiesced fan pages, traditional democratic } \\
\text { intermediaries, MP page's, regional pages }\end{array}$ \\
\hline Logic & $\begin{array}{l}\text { Facebook offers access to millions } \\
\text { of voters; a professionalised party } \\
\text { presence online will help in } \\
\text { elections }\end{array}$ & $\begin{array}{l}\text { Facebook offers new ways to campaign to many } \\
\text { different groups. The capacity to reach and } \\
\text { organise them is tied heavily to the approach } \\
\text { taken. There is room for alternative approaches } \\
\text { rather than replication of a traditional campaign } \\
\text { online }\end{array}$ \\
\hline Activities & $\begin{array}{l}\text { Replicate a broad offline campaign } \\
\text { online to win votes and enthuse } \\
\text { support }\end{array}$ & $\begin{array}{l}\text { Use novel approaches to reach different } \\
\text { demographics/areas, communications using the } \\
\text { language of these groups }\end{array}$ \\
\hline
\end{tabular}


Parties can now use many different types of satellite pages as part of a new methods campaign, with the clandestine use of fan/public pages a recent phenomenon. The use of fan/public pages shows the nefarious aspects of Janus-faced campaigning; parties can use pages that appear out of direct party control but are actively still part of their campaign. Examples of this campaign tactic are becoming more common. During the Brexit referendum Lynton Crosby's CTF partners utilised various 'grassroots' groups to spend up to $£ 1$ million on targeted advertisements (Waterson, 2019). Equally, Scientists for EU, professionalised 116 smaller pro-EU fan pages using a $£ 100,000$ donation to centralise all communications through one office (Manthorpe: 2019). Recently, during the 2019 General Election, public anti-Corbyn pages such as Capitalist Worker, Parents Choice or Third party, advertised in support of the Conservatives. The background operations of these pages showed clear association with the Conservative Party (Hotham, 2020). All these examples show parties branching out within the new methods campaign element of Janus-faced campaigning. It also presents an issue with understanding modern campaigns on Facebook. The clandestine utilisation of satellite pages by political parties means Janus-faced campaigning must be a supply-side concept. It is getting harder to appreciate the pages that constitute Janus-faced campaigning, with the circumstances leading to a blurring of boundaries between what is, and what is not, part of a party's Facebook campaign. Nevertheless, although important, nefarious activity is the extreme end of new methods. Instead, most party activity is part of the visible iceberg, with the varied use of party, leader and party-linked satellite pages the core of Janus-faced campaigning online.

Finally, Janus-faced campaigning is also a fluid concept, as there is both party based nuance towards the traditional and new methods campaigns, as well as clear possibilities for parties to shift their approach over time. Some satellite pages may see themselves dragged in to being part of the traditional campaign as new satellites are 
formed. The evolution of this system will be heavily related to page audience, campaign goal and wider political tactics. Nevertheless, the core approach of multiple satellite pages alongside the party and leader page, is the new campaign normal on Facebook. Janusfaced campaigning thus defines how parties will be campaigning on the platform in future, as party presences on the platform continue to fracture and grow.

In an era of the slow decline of traditional one-step flow communications forms such as television, the rise of multi-level approaches seen in Janus-faced campaigning across both targeted advertising and organic communications, may define a new epoch. Campaigning is moving further away from mass-communications towards microcommunications via smaller groups receiving different messages. Individual voters can be sold different promises, with this presenting new opportunities for political parties, but also presenting new issues for the action of democracy. Academics and activists have repeatedly pointed out the threats of targeted advertising from parties. However, the complexity and diffusion of modern campaigns is seeing potential problems exacerbated across both the targeted and organic campaigns, via official party pages and myriad satellite pages. The variance of organic Facebook campaigning is mirroring trends seen within the wider media system, stimulating further political volatility within Britain.

\section{Methods}

In terms of approach, following some of the best studies in the field (Bene 2017; Magin et al. 2017; Metz et al. 2019), quantitative content analysis (Krippendorf 2018) is used. This allows for the clarity needed to understand approach as pure engagement data, content analysis or microcosmic qualitative study each have limited horizons. While some studies have manually extracted Facebook data (e.g. Williams and Gulati 2013), this study utilised automated collection of basic Facebook data. Automated approaches are useful 
but have certain drawbacks such as the lack of detail within the data. Data collection was performed via Netvizz (Rieder 2013), which allowed for the extraction of basic Facebook public-page activity. To provide a neutral extraction point, a new Facebook account was created, it followed the pages the data was extracted from following recommendations by Netvizz . The posts sent by a page and the associated engagement data (likes, comments and shares over a specified time) were gathered.

It is important to note that the number of posts extractable from Facebook is limited. Netvizz, which like all other legitimate harvesters is constrained by Facebook's API. This dataset used data collected from one month before the 2017 General Election, from the 3rd May to 7th June 2017. Quantitative content analysis is used to examine the features of posts and describes what content approaches are undertaken. This paper follows two literature fields in its quantitative content analysis coding approach. Firstly, in terms of developing an implementable scheme to quantify how parties campaign via content forms, content focussed approaches seen in Alashri et al. (2016), Lee and Campbell (2016) and Bene (2017) are followed. Taking elements of their methods but operating in greater detail, unlike those studies this paper focusses more upon the content analysis and less upon relationships between content and engagement. Secondarily, the coding scheme simplifies major themes seen in wider campaign studies such as in Gibson (2015) and Foot and Schneider's (2006) features analysis.

Content is becoming more complex especially with the rise of video, as such a coding scheme that can appreciate this complexity was developed. The coding approach taken allows posts to be part of all the given categories and does not exclude each post into one set form, instead most of the variables are treated as potentially existing within each post. It is important to appreciate that some related codes can potentially exist at the same time within only one post. For example, in some codes approach is deliberately nondichotomous, a post may feature the positive use of a celebrity alongside the negative use 
of a celebrity, or positive tone and negative tone. This approach has an upside as well as a downside. The upside is that the data this scheme generates is superior to other binary approaches, allowing it to capture video more accurately. The downside of this approach is that it can create issues of double counting within the data, with the use of combined totals for some similar codes limited as they may represent fewer cases than the total describes.

Table 3. How many posts each percentage represents for each page $(n=575)$

\begin{tabular}{rccccc}
\hline & $\begin{array}{c}\text { Number of } \\
\text { posts }\end{array}$ & $2 \%$ & $25 \%$ & $50 \%$ & $100 \%$ \\
\hline Momentum Page & 153 & 3 & 38 & 77 & 153 \\
Labour Party Page & 278 & 6 & 70 & 139 & 278 \\
Jeremy Corbyn Page & 144 & 3 & 36 & 72 & 144 \\
\hline
\end{tabular}

A key issue for this study is data quality. This paper uses a retroactive approach, with analysis of Facebook after an election having positives and negatives. A Facebook page is a museum of interactions frozen in time, and thus is arguably a more solid evaluation foundation as it can reduce bias, because engagement is a stable number. However, the ability to analyse or examine people in the context of an election via experimental approaches is lost, meaning that there is no ability to link social media usage to specific vote choice, e-participation or direct participation offline. Facebook data is also subject to some change over time, for example, some posts are deleted by the parties after posting. Engagement metrics are not $100 \%$ stable over time, while as semi self-reported social data there is also the potential for the data to be inaccurate. This social angle to Facebook data is an important consideration and why the data was checked carefully. The data was cleaned, missing data checked for and incomplete data removed.

To test the quality of the coding of the other datasets Krippendorf's alpha intracoder $(\alpha)$ was used. A paid coder was hired to re-code a set of posts according to the 
coding scheme. $10 \%$ of the posts (58) were sent to be recoded. All binary nominal variables excluding topic issue choice were examined, topic choice was not examined due to the triplicate system. The result was an $\alpha$ of 0.81 which is considered a good result as "it is customary to require $\alpha \geq .8$, while where tentative conclusions are still acceptable, $\alpha$ $\geq .67$ is the lowest conceivable limit" (Krippendorf, 2004, p.241). The results of the testing show a high level of reproducibility via the coding scheme; however, some elements of the coding scheme were more reproducible than others. Information variables received an $\alpha$ of .86, Framing .74, Mobilisation .84 and Personalisation .72. It is clear the less explicit elements of the coding scheme produce more variable results, but that the coding scheme is reliable and represents Facebook communications accurately. Some codes are clearly weaker than others with there a need to appreciate the inherent subjectivity in some elements of Facebook content.

\section{Research Questions}

Three research questions were developed:

- RQ1 - What were the key approaches to information and participation seen from the pages?

- RQ2 - What role does Momentum play in Labour's Facebook campaign?

- RQ3 - Is Labour engaged in Janus-Faced campaigning? 


\section{Empirical Results}

What follows is the coded data presented in several tables across information and participation themes. Tables are separated for legibility.

\section{Information approaches}

Figure 2. Basic content form approaches of the pages $(n=575)$

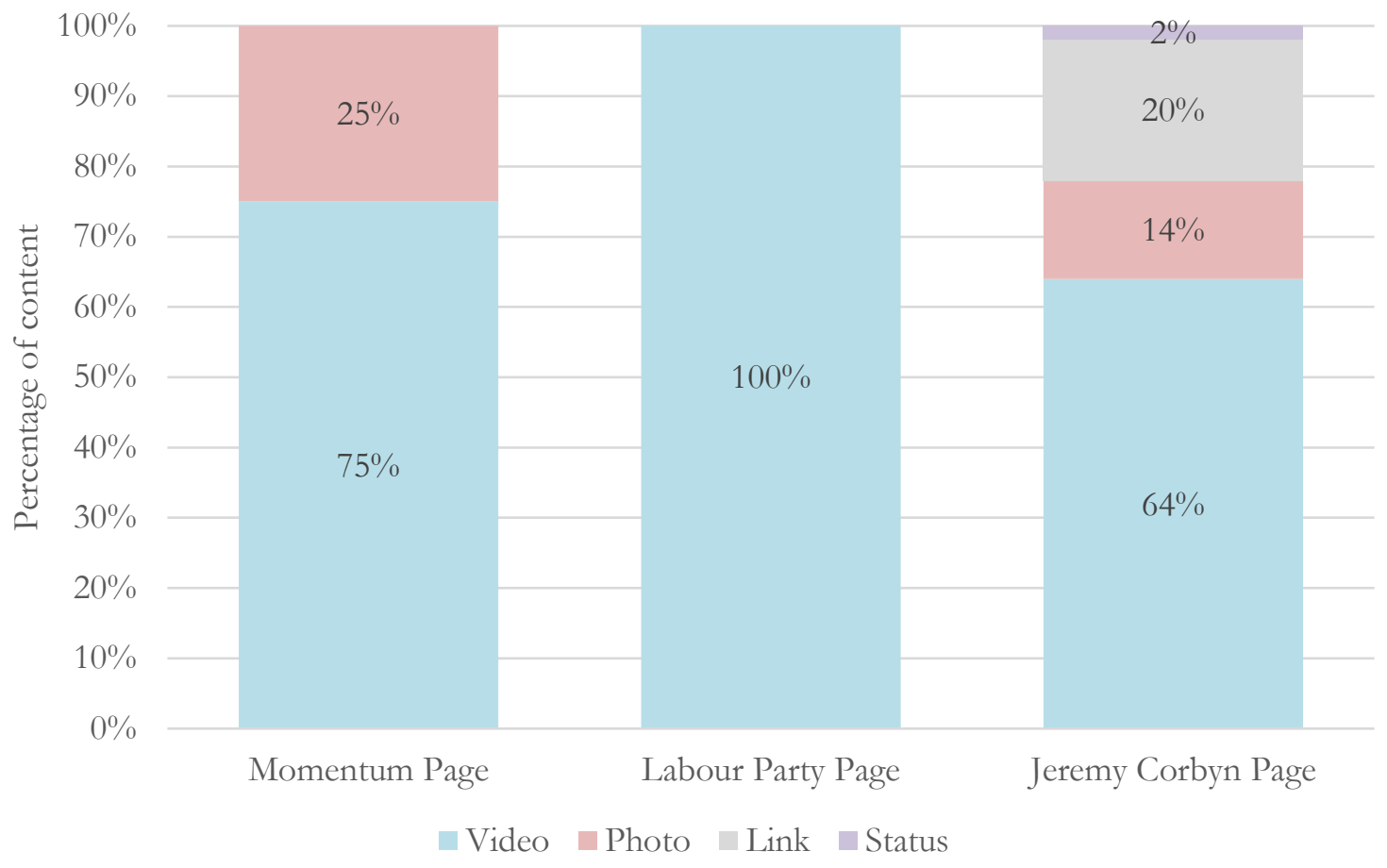


Table 4. Topic approaches $(n=575)$

\begin{tabular}{|c|c|c|c|c|c|c|c|c|c|}
\hline & & Topic 1 & & & Topic 2 & & & Topic 3 & \\
\hline & Momentum & $\begin{array}{l}\text { Labour } \\
\text { Party }\end{array}$ & $\begin{array}{l}\text { Jeremy } \\
\text { Corbyn }\end{array}$ & Momentum & $\begin{array}{l}\text { Labour } \\
\text { Party }\end{array}$ & $\begin{array}{l}\text { Jeremy } \\
\text { Corbyn }\end{array}$ & Momentum & $\begin{array}{l}\text { Labour } \\
\text { Party }\end{array}$ & $\begin{array}{l}\text { Jeremy } \\
\text { Corbyn }\end{array}$ \\
\hline Economy & $12 \%$ & $21 \%$ & $13 \%$ & $7 \%$ & $13 \%$ & $10 \%$ & $4 \%$ & $9 \%$ & $1 \%$ \\
\hline Protection & $10 \%$ & $4 \%$ & $10 \%$ & $5 \%$ & $2 \%$ & $4 \%$ & $3 \%$ & $4 \%$ & $2 \%$ \\
\hline Health and social care & $6 \%$ & $23 \%$ & $14 \%$ & $11 \%$ & $22 \%$ & $10 \%$ & $3 \%$ & $8 \%$ & $3 \%$ \\
\hline Young people & $1 \%$ & $5 \%$ & $3 \%$ & $1 \%$ & $3 \%$ & $3 \%$ & $1 \%$ & $1 \%$ & $1 \%$ \\
\hline Government practice & $0 \%$ & $0 \%$ & $0 \%$ & $0 \%$ & $0 \%$ & $0 \%$ & $0 \%$ & $0 \%$ & $0 \%$ \\
\hline $\begin{array}{c}\text { Environment and } \\
\text { energy }\end{array}$ & $1 \%$ & $1 \%$ & $0 \%$ & $0 \%$ & $0 \%$ & $1 \%$ & $0 \%$ & $0 \%$ & $1 \%$ \\
\hline Party action & $39 \%$ & $25 \%$ & $23 \%$ & $14 \%$ & $15 \%$ & $7 \%$ & $0 \%$ & $6 \%$ & $1 \%$ \\
\hline Leadership & $26 \%$ & $8 \%$ & $14 \%$ & $5 \%$ & $1 \%$ & $5 \%$ & $3 \%$ & $0 \%$ & $0 \%$ \\
\hline Social Identity & $1 \%$ & $8 \%$ & $8 \%$ & $1 \%$ & $2 \%$ & $1 \%$ & $1 \%$ & $0 \%$ & $1 \%$ \\
\hline Education & $1 \%$ & $4 \%$ & $5 \%$ & $2 \%$ & $8 \%$ & $4 \%$ & $0 \%$ & $3 \%$ & $3 \%$ \\
\hline Apolitical & $2 \%$ & $0 \%$ & $6 \%$ & $0 \%$ & $0 \%$ & $1 \%$ & $1 \%$ & $0 \%$ & $0 \%$ \\
\hline Immigration & $0 \%$ & $0 \%$ & $1 \%$ & $0 \%$ & $0 \%$ & $0 \%$ & $1 \%$ & $0 \%$ & $0 \%$ \\
\hline $\mathrm{EU}$ & $1 \%$ & $1 \%$ & $3 \%$ & $1 \%$ & $0 \%$ & $0 \%$ & $0 \%$ & $0 \%$ & $0 \%$ \\
\hline Sum of topics & $100 \%$ & $100 \%$ & $100 \%$ & $47 \%$ & $66 \%$ & $46 \%$ & $17 \%$ & $31 \%$ & $13 \%$ \\
\hline
\end{tabular}


Table 5. Information features of Labour Party, Jeremy Corbyn and Momentum 2017 posts (Code Group 1) $(\mathrm{n}=575)$

\begin{tabular}{|c|c|c|c|c|c|c|c|}
\hline & & \multicolumn{2}{|c|}{ Momentum } & \multicolumn{2}{|c|}{ Labour Party } & \multicolumn{2}{|c|}{ Jeremy Corbyn } \\
\hline & & $n$ & $\%$ & $n$ & $\%$ & $n$ & $\%$ \\
\hline \multirow[t]{5}{*}{ Basic content form } & Video content & 115 & $75.0 \%$ & 278 & $100.0 \%$ & 92 & $64.0 \%$ \\
\hline & Photo content & 38 & $25.0 \%$ & 0 & $0.0 \%$ & 20 & $14.0 \%$ \\
\hline & Status content & 0 & $0.0 \%$ & 0 & $0.0 \%$ & 3 & $2.0 \%$ \\
\hline & Link content & 0 & $0.0 \%$ & 0 & $0.0 \%$ & 29 & $20.0 \%$ \\
\hline & Basic content form sum & 153 & $100.0 \%$ & 278 & $100.0 \%$ & 144 & $100.0 \%$ \\
\hline \multirow[t]{6}{*}{ Video forms in detail } & Video uses mainstream media content & 32 & $20.9 \%$ & 9 & $3.2 \%$ & 26 & $18.1 \%$ \\
\hline & Video uses alternative media content & 4 & $2.6 \%$ & 0 & $0.0 \%$ & 0 & $0.0 \%$ \\
\hline & Video is Party Election Broadcast & 0 & $0.0 \%$ & 18 & $6.5 \%$ & 4 & $2.8 \%$ \\
\hline & Infographic video & 6 & $3.9 \%$ & 161 & $57.9 \%$ & 11 & $7.6 \%$ \\
\hline & Facebook Live video & 4 & $2.6 \%$ & 5 & $1.8 \%$ & 3 & $2.1 \%$ \\
\hline & Music video & 3 & $2.0 \%$ & 0 & $0.0 \%$ & 0 & $0.0 \%$ \\
\hline \multirow[t]{8}{*}{ Photo forms in detail } & Image & 25 & $16.3 \%$ & 0 & $0.0 \%$ & 31 & $21.5 \%$ \\
\hline & Newspaper front-page & 1 & $0.7 \%$ & 0 & $0.0 \%$ & 0 & $0.0 \%$ \\
\hline & Image collection & 2 & $1.3 \%$ & 1 & $0.4 \%$ & 1 & $0.7 \%$ \\
\hline & Text only image & 16 & $10.5 \%$ & 0 & $0.0 \%$ & 1 & $0.7 \%$ \\
\hline & Poster & 4 & $2.6 \%$ & 1 & $0.4 \%$ & 12 & $8.3 \%$ \\
\hline & Meme & 21 & $13.7 \%$ & 0 & $0.0 \%$ & 1 & $0.7 \%$ \\
\hline & Infographic image & 7 & $4.6 \%$ & 0 & $0.0 \%$ & 3 & $2.1 \%$ \\
\hline & Twitter screen capture & 29 & $19.0 \%$ & 0 & $0.0 \%$ & 0 & $0.0 \%$ \\
\hline \multirow[t]{5}{*}{ Other content forms } & Audio & 0 & $0.0 \%$ & 0 & $0.0 \%$ & 0 & $0.0 \%$ \\
\hline & Features external link to website & 54 & $35.3 \%$ & 51 & $18.3 \%$ & 31 & $21.5 \%$ \\
\hline & Image is now defunct & 0 & $0.0 \%$ & 0 & $0.0 \%$ & 1 & $0.7 \%$ \\
\hline & Business endorsement & 0 & $0.0 \%$ & 0 & $0.0 \%$ & 0 & $0.0 \%$ \\
\hline & Text only post & 0 & $0.0 \%$ & 0 & $0.0 \%$ & 1 & $0.7 \%$ \\
\hline
\end{tabular}


Table 6. Information features of Labour Party, Jeremy Corbyn and Momentum 2017 posts (Code Group 2) $(\mathrm{n}=575)$

\begin{tabular}{|c|c|c|c|c|c|c|c|}
\hline & & \multicolumn{2}{|c|}{ Momentum } & \multicolumn{2}{|c|}{ Labour Party } & \multicolumn{2}{|c|}{ Jeremy Corbyn } \\
\hline & & $n$ & $\%$ & $n$ & $\%$ & $n$ & $\%$ \\
\hline \multirow[t]{5}{*}{ Sentiment orientation } & Post features political information & 150 & $98.0 \%$ & 278 & $100.0 \%$ & 114 & $79.2 \%$ \\
\hline & Positive orientation & 109 & $71.2 \%$ & 246 & $88.5 \%$ & 88 & $61.1 \%$ \\
\hline & Negative orientation & 72 & $47.1 \%$ & 80 & $28.8 \%$ & 64 & $44.4 \%$ \\
\hline & More negative than positive (primary focus) & 42 & $27.5 \%$ & 44 & $15.8 \%$ & 50 & $34.7 \%$ \\
\hline & More positive than negative & 111 & $72.5 \%$ & 234 & $84.2 \%$ & 94 & $65.3 \%$ \\
\hline \multirow[t]{9}{*}{ Information quality } & Use of policy detail & 20 & $13.1 \%$ & 160 & $57.6 \%$ & 56 & $38.9 \%$ \\
\hline & Content is mainly rhetorical in nature not factual & 83 & $54.2 \%$ & 65 & $23.4 \%$ & 86 & $59.7 \%$ \\
\hline & Use of external media or news content altered by party & 64 & $41.8 \%$ & 9 & $3.2 \%$ & 34 & $23.6 \%$ \\
\hline & Positive use of external media or news content altered by party & 37 & $24.2 \%$ & 1 & $0.4 \%$ & 14 & $9.7 \%$ \\
\hline & Negative use of external media or news content altered by party & 33 & $21.6 \%$ & 8 & $2.9 \%$ & 19 & $13.2 \%$ \\
\hline & Use of positive valence issue & 21 & $13.7 \%$ & 152 & $54.7 \%$ & 76 & $52.8 \%$ \\
\hline & Use of negative valence issue & 34 & $22.2 \%$ & 62 & $22.3 \%$ & 55 & $38.2 \%$ \\
\hline & Use of positive position issue & 26 & $17.0 \%$ & 163 & $58.6 \%$ & 73 & $50.7 \%$ \\
\hline & Use of negative position issue & 43 & $28.1 \%$ & 67 & $24.1 \%$ & 58 & $40.3 \%$ \\
\hline \multirow[t]{10}{*}{ Framing } & Pledge & 16 & $10.5 \%$ & 184 & $66.2 \%$ & 84 & $58.3 \%$ \\
\hline & Diagnosis & 141 & $92.2 \%$ & 251 & $90.3 \%$ & 113 & $78.5 \%$ \\
\hline & Negative problem is diagnosed & 115 & $75.2 \%$ & 211 & $75.9 \%$ & 105 & $72.9 \%$ \\
\hline & Positive success is diagnosed & 41 & $26.8 \%$ & 58 & $20.9 \%$ & 21 & $14.6 \%$ \\
\hline & Prognosis & 80 & $52.3 \%$ & 249 & $89.6 \%$ & 98 & $68.1 \%$ \\
\hline & Positive prognosis - how we will solve problem & 79 & $51.6 \%$ & 249 & $89.6 \%$ & 93 & $64.6 \%$ \\
\hline & Negative prognosis - how problem won't be solved & 12 & $7.8 \%$ & 53 & $19.1 \%$ & 33 & $22.9 \%$ \\
\hline & Motivation and ideology & 40 & $26.1 \%$ & 151 & $54.3 \%$ & 84 & $58.3 \%$ \\
\hline & Motivation why a problem should be solved & 40 & $26.1 \%$ & 151 & $54.3 \%$ & 83 & $57.6 \%$ \\
\hline & Motivation why the party solved a problem & 3 & $2.0 \%$ & 1 & $0.4 \%$ & 2 & $1.4 \%$ \\
\hline
\end{tabular}


Table 7. Information features of Labour Party, Jeremy Corbyn and Momentum 2017 posts (Code Group 3) $(\mathrm{n}=575)$

\begin{tabular}{|c|c|c|c|c|c|c|c|}
\hline & & \multicolumn{2}{|c|}{ Momentum } & \multicolumn{2}{|c|}{ Labour Party } & \multicolumn{2}{|c|}{ Jeremy Corbyn } \\
\hline & & $n$ & $\%$ & $n$ & $\%$ & $n$ & $\%$ \\
\hline \multirow[t]{7}{*}{ Rhetoric and imagery } & Use of patriotic imagery & 2 & $1.3 \%$ & 11 & $4.0 \%$ & 11 & $7.6 \%$ \\
\hline & Use of repetition & 44 & $28.8 \%$ & 61 & $21.9 \%$ & 63 & $43.8 \%$ \\
\hline & Use of 'us versus them' rhetoric & 36 & $23.5 \%$ & 106 & $38.1 \%$ & 56 & $38.9 \%$ \\
\hline & Use of three-part list & 21 & $13.7 \%$ & 131 & $47.1 \%$ & 41 & $28.5 \%$ \\
\hline & Use of party catch phrase & 9 & $5.9 \%$ & 222 & $79.9 \%$ & 100 & $69.4 \%$ \\
\hline & Use of colloquialisms & 10 & $6.5 \%$ & 3 & $1.1 \%$ & 2 & $1.4 \%$ \\
\hline & Use of informal language & 19 & $12.4 \%$ & 3 & $1.1 \%$ & 2 & $1.4 \%$ \\
\hline \multirow[t]{8}{*}{ Use of celebrity or expert } & Celebrity endorsement & 20 & $13.1 \%$ & 47 & $16.9 \%$ & 19 & $13.2 \%$ \\
\hline & Use of male celebrity & 21 & $13.7 \%$ & 35 & $12.6 \%$ & 11 & $7.6 \%$ \\
\hline & Use of female celebrity & 3 & $2.0 \%$ & 18 & $6.5 \%$ & 9 & $6.3 \%$ \\
\hline & Positive use of non-political expert & 21 & $13.7 \%$ & 14 & $5.0 \%$ & 13 & $9.0 \%$ \\
\hline & Negative use of non-political expert & 10 & $6.5 \%$ & 10 & $3.6 \%$ & 6 & $4.2 \%$ \\
\hline & Positive use of party-political expert & 13 & $8.5 \%$ & 13 & $4.7 \%$ & 9 & $6.3 \%$ \\
\hline & Negative use of party-political expert & 1 & $0.7 \%$ & 5 & $1.8 \%$ & 4 & $2.8 \%$ \\
\hline & Use of an experts personal story & 14 & $9.2 \%$ & 22 & $7.9 \%$ & 6 & $4.2 \%$ \\
\hline \multirow[t]{8}{*}{$\begin{array}{l}\text { Use of identity } \\
\text { ownership/depiction }\end{array}$} & In text use of relevant public worker to issue raised & 11 & $7.2 \%$ & 22 & $7.9 \%$ & 9 & $6.3 \%$ \\
\hline & Use of general public's voice & 36 & $23.5 \%$ & 24 & $8.6 \%$ & 15 & $10.4 \%$ \\
\hline & Non-political personal public story & 15 & $9.8 \%$ & 25 & $9.0 \%$ & 17 & $11.8 \%$ \\
\hline & Video and imagery use of relevant public worker to issue raised & 41 & $26.8 \%$ & 59 & $21.2 \%$ & 25 & $17.4 \%$ \\
\hline & In-text use of ordinary public & 22 & $14.4 \%$ & 136 & $48.9 \%$ & 78 & $54.2 \%$ \\
\hline & Video and imagery use of ordinary public & 71 & $46.4 \%$ & 131 & $47.1 \%$ & 73 & $50.7 \%$ \\
\hline & In-text use of minority ordinary public & 1 & $0.7 \%$ & 0 & $0.0 \%$ & 3 & $2.1 \%$ \\
\hline & Video and imagery use of minority ordinary public & 22 & $14.4 \%$ & 75 & $27.0 \%$ & 33 & $22.9 \%$ \\
\hline
\end{tabular}


Table 8. Information features of Labour Party, Jeremy Corbyn and Momentum 2017 posts (Code Group 4) $(n=575)$

\begin{tabular}{|c|c|c|c|c|c|c|c|}
\hline & & \multicolumn{2}{|c|}{ Momentum } & \multicolumn{2}{|c|}{ Labour Party } & \multicolumn{2}{|c|}{ Jeremy Corbyn } \\
\hline & & $n$ & $\%$ & $n$ & $\%$ & $n$ & $\%$ \\
\hline \multirow[t]{12}{*}{ Use of media } & Positive use of mainstream media & 19 & $12.4 \%$ & 1 & $0.4 \%$ & 18 & $12.5 \%$ \\
\hline & Negative use of mainstream media & 21 & $13.7 \%$ & 13 & $4.7 \%$ & 18 & $12.5 \%$ \\
\hline & Positive use of external newspaper source & 0 & $0.0 \%$ & 0 & $0.0 \%$ & 2 & $1.4 \%$ \\
\hline & Negative use of external newspaper source & 1 & $0.7 \%$ & 5 & $1.8 \%$ & 4 & $2.8 \%$ \\
\hline & Positive use of external newspaper source via link & 0 & $0.0 \%$ & 0 & $0.0 \%$ & 4 & $2.8 \%$ \\
\hline & Negative use of external newspaper source via link & 0 & $0.0 \%$ & 0 & $0.0 \%$ & 4 & $2.8 \%$ \\
\hline & Positive use of alternative media & 9 & $5.9 \%$ & 0 & $0.0 \%$ & 0 & $0.0 \%$ \\
\hline & Negative use of alternative media & 1 & $0.7 \%$ & 0 & $0.0 \%$ & 0 & $0.0 \%$ \\
\hline & Media endorsement & 0 & $0.0 \%$ & 0 & $0.0 \%$ & 0 & $0.0 \%$ \\
\hline & Attack on other media & 2 & $1.0 \%$ & 0 & $0.0 \%$ & 0 & $0.0 \%$ \\
\hline & Use of polling & 9 & $5.9 \%$ & 0 & $0.0 \%$ & 0 & $0.0 \%$ \\
\hline & Use of screen capture of tweet & 29 & $19.0 \%$ & 0 & $0.0 \%$ & 0 & $0.0 \%$ \\
\hline \multirow[t]{4}{*}{ Classical personalisation } & Use of apolitical personal information and interests & 9 & $5.9 \%$ & 15 & $5.4 \%$ & 9 & $6.3 \%$ \\
\hline & Use of leaders personal family & 3 & $2.0 \%$ & 1 & $0.4 \%$ & 0 & $0.0 \%$ \\
\hline & Use of first person language & 71 & $46.4 \%$ & 52 & $18.7 \%$ & 57 & $39.6 \%$ \\
\hline & Use of a personal message (not a political issue) & 32 & $20.9 \%$ & 15 & $5.4 \%$ & 19 & $13.2 \%$ \\
\hline \multirow[t]{5}{*}{$\begin{array}{l}\text { Positive leadership } \\
\text { personalisation }\end{array}$} & Post is positively personalised & 65 & $42.5 \%$ & 53 & $19.1 \%$ & 84 & $58.3 \%$ \\
\hline & Praise of Leader & 55 & $35.9 \%$ & 43 & $15.5 \%$ & 7 & $4.9 \%$ \\
\hline & Use of party leader in video & 46 & $30.1 \%$ & 39 & $14.0 \%$ & 55 & $38.2 \%$ \\
\hline & Use of party leader in text & 24 & $15.7 \%$ & 27 & $9.7 \%$ & 6 & $4.2 \%$ \\
\hline & Use of party leader in non-video imagery & 10 & $6.5 \%$ & 0 & $0.0 \%$ & 18 & $12.5 \%$ \\
\hline \multirow[t]{5}{*}{$\begin{array}{l}\text { Negative leadership } \\
\text { personalisation }\end{array}$} & Post is negatively personalised & 50 & $32.7 \%$ & 34 & $12.2 \%$ & 41 & $28.5 \%$ \\
\hline & Negative appraisal of opposition leader & 45 & $29.4 \%$ & 31 & $11.2 \%$ & 38 & $26.4 \%$ \\
\hline & Use of opposition leader in video & 34 & $22.2 \%$ & 29 & $10.4 \%$ & 24 & $16.7 \%$ \\
\hline & Use of opposition leader in text & 21 & $13.7 \%$ & 14 & $5.0 \%$ & 25 & $17.4 \%$ \\
\hline & Use of opposition leader in non-video imagery & 7 & $4.6 \%$ & 0 & $0.0 \%$ & 5 & $3.5 \%$ \\
\hline
\end{tabular}


Table 9. Information features of Labour Party, Jeremy Corbyn and Momentum 2017 posts (Code Group 5) $(\mathrm{n}=575)$

\begin{tabular}{|c|c|c|c|c|c|c|c|}
\hline & & \multicolumn{2}{|c|}{ Momentum } & \multicolumn{2}{|c|}{ Labour Party } & \multicolumn{2}{|c|}{ Jeremy Corbyn } \\
\hline & & $n$ & $\%$ & $n$ & $\%$ & $n$ & $\%$ \\
\hline \multirow[t]{5}{*}{$\begin{array}{l}\text { Positive wider party } \\
\text { personalisation }\end{array}$} & Praise of party MP/MPs & 3 & $2.0 \%$ & 11 & $4.0 \%$ & 7 & $4.9 \%$ \\
\hline & Praise of former party leader & 1 & $0.7 \%$ & 1 & $0.4 \%$ & 0 & $0.0 \%$ \\
\hline & Use of party politician in video & 6 & $3.9 \%$ & 17 & $6.1 \%$ & 8 & $5.6 \%$ \\
\hline & Use of party politician in text & 6 & $3.9 \%$ & 12 & $4.3 \%$ & 10 & $6.9 \%$ \\
\hline & Use of party politician in non-video imagery & 6 & $3.9 \%$ & 0 & $0.0 \%$ & 5 & $3.5 \%$ \\
\hline \multirow[t]{4}{*}{$\begin{array}{l}\text { Negative opposition party } \\
\text { personalisation }\end{array}$} & Negative appraisal of opposition MP/MPs & 8 & $5.2 \%$ & 7 & $2.5 \%$ & 8 & $5.6 \%$ \\
\hline & Use of opposition party politician in video & 4 & $2.6 \%$ & 7 & $2.5 \%$ & 3 & $2.1 \%$ \\
\hline & Use of opposition party politician in text & 3 & $2.0 \%$ & 1 & $0.4 \%$ & 3 & $2.1 \%$ \\
\hline & Use of opposition party politician in non-video imagery & 4 & $2.6 \%$ & 0 & $0.0 \%$ & 1 & $0.7 \%$ \\
\hline \multirow[t]{2}{*}{ Internal partisanship } & Negative expressions about same party politicians & 0 & $0.0 \%$ & 0 & $0.0 \%$ & 0 & $0.0 \%$ \\
\hline & Negative appraisal of same party former leader & 1 & $0.7 \%$ & 0 & $0.0 \%$ & 0 & $0.0 \%$ \\
\hline \multirow[t]{2}{*}{ Positive partisanship } & Praise of party members & 9 & $5.9 \%$ & 13 & $4.7 \%$ & 9 & $6.3 \%$ \\
\hline & Praise of party campaigners & 15 & $9.8 \%$ & 18 & $6.5 \%$ & 10 & $6.9 \%$ \\
\hline \multirow[t]{2}{*}{ Negative partisanship } & Negative appraisal of opposition party members & 0 & $0.0 \%$ & 0 & $0.0 \%$ & 1 & $0.7 \%$ \\
\hline & Negative appraisal of opposition party campaigners & 0 & $0.0 \%$ & 0 & $0.0 \%$ & 2 & $1.4 \%$ \\
\hline \multirow[t]{4}{*}{ Use of humour } & Use of humour & 39 & $25.5 \%$ & 9 & $3.2 \%$ & 10 & $6.9 \%$ \\
\hline & Use of political humour & 26 & $17.0 \%$ & 2 & $0.7 \%$ & 7 & $4.9 \%$ \\
\hline & Use of general apolitical humour & 23 & $15.0 \%$ & 7 & $2.5 \%$ & 4 & $2.8 \%$ \\
\hline & Use of meme style humour & 18 & $11.8 \%$ & 2 & $0.7 \%$ & 0 & $0.0 \%$ \\
\hline
\end{tabular}




\section{Participation approaches}

Table 10. Participation features of Labour Party, Jeremy Corbyn and Momentum 2017 posts (Code Group 6) $(n=575)$

\begin{tabular}{|c|c|c|c|c|c|c|c|}
\hline & & \multicolumn{2}{|c|}{ Momentum } & \multicolumn{2}{|c|}{ Labour Party } & \multicolumn{2}{|c|}{ Jeremy Corbyn } \\
\hline & & $n$ & $\%$ & $n$ & $\%$ & $n$ & $\%$ \\
\hline \multirow[t]{7}{*}{ Offline participation } & Help doorstep campaign & 73 & $47.7 \%$ & 19 & $6.8 \%$ & 4 & $3.5 \%$ \\
\hline & Volunteer & 75 & $49.0 \%$ & 19 & $6.8 \%$ & 4 & $2.8 \%$ \\
\hline & Call for vote & 18 & $11.8 \%$ & 237 & $85.3 \%$ & 85 & $59.0 \%$ \\
\hline & Attend protest & 0 & $0.0 \%$ & 0 & $0.0 \%$ & 0 & $0.0 \%$ \\
\hline & Visit event & 2 & $1.3 \%$ & 0 & $0.0 \%$ & 3 & $2.1 \%$ \\
\hline & Attend hustings & 0 & $0.0 \%$ & 0 & $0.0 \%$ & 0 & $0.0 \%$ \\
\hline & Attend rally & 1 & $0.7 \%$ & 0 & $0.0 \%$ & 2 & $1.4 \%$ \\
\hline \multirow[t]{14}{*}{ Online participation } & Call to visit party website & 81 & $52.9 \%$ & 33 & $11.9 \%$ & 5 & $3.5 \%$ \\
\hline & Visit campaign page & 68 & $44.4 \%$ & 33 & $11.9 \%$ & 6 & $4.2 \%$ \\
\hline & Sign up to campaign offline & 72 & $47.1 \%$ & 19 & $6.8 \%$ & 5 & $3.5 \%$ \\
\hline & Call to visit another website & 8 & $5.2 \%$ & 35 & $12.6 \%$ & 27 & $18.8 \%$ \\
\hline & Join party & 3 & $2.0 \%$ & 0 & $0.0 \%$ & 0 & $0.0 \%$ \\
\hline & Register to vote & 5 & $3.3 \%$ & 36 & $12.9 \%$ & 16 & $11.1 \%$ \\
\hline & Call to share I'm voting message & 0 & $0.0 \%$ & 6 & $2.2 \%$ & 0 & $0.0 \%$ \\
\hline & Call to join/visit other internet medium & 0 & $0.0 \%$ & 0 & $0.0 \%$ & 1 & $0.7 \%$ \\
\hline & Call to join/visit other social media & 0 & $0.0 \%$ & 0 & $0.0 \%$ & 2 & $1.4 \%$ \\
\hline & Poll & 0 & $0.0 \%$ & 0 & $0.0 \%$ & 0 & $0.0 \%$ \\
\hline & Sign petition & 2 & $1.3 \%$ & 0 & $0.0 \%$ & 0 & $0.0 \%$ \\
\hline & Give funding & 8 & $5.2 \%$ & 2 & $0.7 \%$ & 2 & $1.4 \%$ \\
\hline & Visit shop & 1 & $0.7 \%$ & 0 & $0.0 \%$ & 0 & $0.0 \%$ \\
\hline & Change your profile picture & 0 & $0.0 \%$ & 0 & $0.0 \%$ & 0 & $0.0 \%$ \\
\hline Online/Offline participation & Call to talk to friends and family & 15 & $9.8 \%$ & 5 & $1.8 \%$ & 10 & $6.9 \%$ \\
\hline
\end{tabular}


Table 11. Participation features of Labour Party, Jeremy Corbyn and Momentum 2017 posts (Code Group 7) $(\mathrm{n}=575)$

\begin{tabular}{|c|c|c|c|c|c|c|c|}
\hline & & \multicolumn{2}{|c|}{ Momentum } & \multicolumn{2}{|c|}{ Labour Party } & \multicolumn{2}{|c|}{ Jeremy Corbyn } \\
\hline & & $n$ & $\%$ & $n$ & $\%$ & $n$ & $\%$ \\
\hline \multirow[t]{4}{*}{ Engagement } & Call to share & 49 & $32.0 \%$ & 165 & $59.4 \%$ & 12 & $8.3 \%$ \\
\hline & Call to comment & 0 & $0.0 \%$ & 1 & $0.4 \%$ & 3 & $2.1 \%$ \\
\hline & Call to like & 2 & $1.3 \%$ & 4 & $1.4 \%$ & 1 & $0.7 \%$ \\
\hline & Call to tag Facebook friends & 2 & $1.3 \%$ & 1 & $0.4 \%$ & 3 & $2.1 \%$ \\
\hline \multirow[t]{8}{*}{ Active links } & Link to Facebook page - other type of page & 23 & $15.0 \%$ & 24 & $8.6 \%$ & 20 & $13.9 \%$ \\
\hline & Link to Facebook page - same party & 13 & $8.5 \%$ & 32 & $11.5 \%$ & 44 & $30.6 \%$ \\
\hline & Link to Facebook mainstream news group & 3 & $2.0 \%$ & 0 & $0.0 \%$ & 6 & $4.2 \%$ \\
\hline & Link to Facebook alternative news group & 0 & $0.0 \%$ & 0 & $0.0 \%$ & 0 & $0.0 \%$ \\
\hline & Link to Facebook opposition party or leader page & 4 & $2.6 \%$ & 4 & $1.4 \%$ & 35 & $24.3 \%$ \\
\hline & Link to other social media network Twitter & 0 & $0.0 \%$ & 0 & $0.0 \%$ & 0 & $0.0 \%$ \\
\hline & Link to other social media network Instagram & 0 & $0.0 \%$ & 0 & $0.0 \%$ & 0 & $0.0 \%$ \\
\hline & Link to other social media network YouTube & 0 & $0.0 \%$ & 0 & $0.0 \%$ & 0 & $0.0 \%$ \\
\hline \multirow[t]{5}{*}{ Data gathering } & Give location & 7 & $4.6 \%$ & 2 & $0.7 \%$ & 5 & $3.5 \%$ \\
\hline & Give data to party website & 2 & $1.3 \%$ & 2 & $0.7 \%$ & 4 & $2.8 \%$ \\
\hline & Give email address & 2 & $1.3 \%$ & 2 & $0.7 \%$ & 4 & $2.8 \%$ \\
\hline & Give name & 2 & $1.3 \%$ & 2 & $0.7 \%$ & 4 & $2.8 \%$ \\
\hline & Give phone number & 2 & $1.3 \%$ & 2 & $0.7 \%$ & 5 & $3.5 \%$ \\
\hline
\end{tabular}




\section{Discussion}

What were the key approaches to information and participation seen from the pages?

\section{Information approaches}

\section{Content form}

The first key area of analysis is content structure. Examining the 2017 General Election, Momentum followed the Labour Party page's video trend. Momentum's posts in 2017 were $75 \%$ video content, behind the Labour Party page (100\%) but ahead of Corbyn's page (64\%). Momentum is following the latest trends in campaign information delivery despite reduced resources, the group does not suffer from a normalisation gap. The high use of video speaks to Momentum's integration within modern understandings of how social media works, with usage showing that reduced monetary resources is no barrier to video content. There are clear differences between the pages, especially in the use of links and the amount of video used. However, generally a coherent trend is visible, with video clearly in supremacy and then photo or link content subsidiary.

Examining video across the 2017 General election, Momentum's approach was particularly different to the Labour Party page and closer to Jeremy Corbyn's page. Unlike the Labour Party page, Momentum did not extensively utilise infographic videos (4\%), instead they favoured mainstream media content (21\%). Momentum consistently reused media especially news, but also other cultural programming like Question Time or comedy staples like The Office. Momentum spoke in a different more experimental way, with this further seen through their application of Facebook Live (3\%), alternative media (3\%) and music videos (2\%). The group avoided talking like a political party, they did not use any PEBs and avoided long-form content, highlighting the younger digital savvy 
audience they wanted to reach. Momentum utilised novel methods, with the organisation standing outside of the remit of the traditional Facebook campaign. Momentum was able to innovate by trying new things to reach a different audience than the leader or party page. Some of the approaches seen (such as music videos) were clearly used to reach the general public, rather than virtual or official member support. In 2017 Momentum had a real belief in novel viral content for public consumption, a tactic that worked so well that Momentum's video content was re-used during the 2019 General Election.

Examining photo approaches in detail, although overall use of photo was remarkably similar between Corbyn and Momentum's page across the 2017 election, Momentum clearly used more novel approaches to the form. Momentum extensively used meme's, with $14 \%$ of their content meme's, against $0 \%$ for the party page and $1 \%$ for Corbyn. The use of meme's shows Momentum was pushing boundaries, using the language of the internet to communicate in a new way to a different audience. Momentum was utilising what is referred to as mediated authenticity (Enli 2017), their position as a satellite campaign allowed the organisation to use a humorous tone that the more serious pages could not. Another key difference across the election was Momentum's use of textonly images (10\%), a defunct format across all the other pages studied, the high incidence rate is mainly due to the use of screen captures of Twitter comments (19\%). Momentum extensively brought Twitter content to Facebook, this interlinking of two social networks shows how Momentum treated Facebook as part of a wider social network eco-system, but only as an information source. Twitter content was used but not linked, users were not promoted to leave the page. Instead, Twitter content was used on Facebook to feed into the formation of a collective identity (akin to that seen with movement parties as per Kavada, 2019), and help develop the narrative of left versus right politics. Momentum thus used Twitter content to inflame partisan passions and prompt activity on Facebook itself. 


\section{Content topics}

In the topics sent, firstly Momentum was not used to deliver as many political topics (1.63) as the party page (1.98), with the page using a similar number of topics per post to Corbyn's page (1.60). Both Momentum and Corbyn's page fit in as a middle information tool, in contrast the official party page takes on the role of disseminating more complex information. The focus of the Corbyn and Momentum pages' is centred less on policy and core political issues, instead they are more focused on ideas and actions. Examining the topics covered, Momentum's main 2017 topics centred on the economy, protection, party action and leadership. There was a 59pp primary topic choice difference between Momentum and Corbyn's page, as opposed to 79pp for the Labour Party page. Although Momentum's approach mirrors some elements of the Labour and Corbyn page, the group sent by far the least broad range of primary topics. $86 \%$ of content occurred from the five most used topics, as opposed to $64 \%$ for the party page and $60 \%$ for the leader page. A large amount of focus was placed on two areas, with $64 \%$ of primary topic content centred on leadership and party action. Momentum as an organisation in-part founded to support Corbyn and his politics, understandably has high rates of leadership content $(26 \%)$. The party heavily fed into Corbynmania and heavily personalised the leader. Momentum's even greater focus on party action content (39\%) shows a role apart from the other pages. As examined later when looking at participation approaches, the group heavily focused on activating the public and virtual members.

Although Momentum's topic use expanded across subsequent topic choices, compared to the other Labour pages they were unconcerned with promoting electorally important policy areas, such as social care or the economy. The page was not primarily concerned with political information and policy, leaving these elements to the traditional Facebook campaign. Instead, Momentum's satellite campaign was designed to energise 
certain elements of the electorate, engage with more radical information topics and engender virtual member participation. This was not a narrow approach however, the group showed disinterest in narrowcast social identity or young people focussed content. This is surprising given that the organisation is thought to be narrow in focus; being youth orientated and interested in issues of racism, equality and social justice. Instead, during the election Momentum was trying to reach a large more radical group of voting public than the party or leader page.

Content quality

The trends seen across topic choice, including the role of Momentum as a tool not centred on policy and political information but instead on participation, organisation and leadership, is clearly also seen in use of policy detail. Momentum across 2017 featured low levels of policy detail (13\%), although levels of political information were still high (97\%). The organisation delivered political information but was focussed on broader debates and ideas related to politics, not direct policy. The differences across the pages show the official party page used for detailed information, Momentum for ideological political information and Corbyn's page for a mixture of both. The sentiment of the political information delivered is also different across the pages. Momentum featured more negative political information $(52 \%)$ than the leader $(44 \%)$ or party page $(31 \%)$, alongside less positive information (71\%) than the party page $(90 \%)$. In the sentiment of the political information used, Momentum more closely follows Corbyn's page than the party page, the group communicates in a more emotionally charged manner, showing their interest in speaking to a more partisan audience.

The use of position issues also varies by page, Momentum (17\%) features similar positive position issue use to Corbyn's page (16\%), with the Labour Party page using 
more of the form (51\%). Negative position issues are also more clearly used by the leader (40\%) and party page (40\%) rather than Momentum. Some commentators and Labour MP's have criticised Momentum as a Militant-style organisation ${ }^{1}$, asserting the group to be particularly left wing and radical. However, it was the more moderate Labour Party page that pushed these combative ideological position issues. In contrast, Momentum and Corbyn pushed a broader political idealism that was an inclusive vision and not focused on combative policy.

Use of expertise or celebrity

Facebook offers new avenues for the utilisation of experts and celebrities, with satellite campaigns offering even greater scope for the use of cultural figures that can speak to different audiences. Due to their smaller audience targets, satellite campaigns such as Momentum can use more specific experts or celebrities than the party or leader page. This is seen within Momentum, as well-respected left of centre academics such as Joseph Stieglitz and Noam Chomsky are used as experts, while other important cultural figures such as Stormzy are used as celebrities. Overall, the data shows that in contrast to the leader and party page's, Momentum is much more interested in using experts than celebrities. As Momentum champions more radical causes, experts are used to argue ideological positions within a wider left-wing vision. Equally, Momentum uses experts like celebrities, as figures such as Noam Chomsky have a large amount of cultural capital as left-wing figures.

${ }^{1}$ https://www.theguardian.com/politics/2017/mar/18/secret-tape-reveals-momentum-plot-tolink-with-unite-seize-control-of-labour accessed - 4/9/2019 
Examining the use of expertise in detail. Momentum like the other Labour pages favoured using non-political experts over party-political experts. The pages appreciate the influence sources outside the party can have for persuasion. Usage of experts during the election campaign was generally positive. $14 \%$ of 2017 Momentum election content used non-political experts positively, with usage rates far above Corbyn (9\%) or the Labour Party page (5\%). Momentum's use of experts was also higher (7\%) compared to the other pages (4\%). Momentum's celebrities were more specific opinion leaders, including leftwing figures such as Michael Rosen or Billy Bragg, or important figures within minority communities such as Stormzy. In contrast, the traditional campaign focused on household names such as Steve Coogan. Labour clearly had an appreciation of the way different celebrities can influence different sociological networks, with Momentum using celebrities to break into communities more likely open to Momentum's more radical message. Overall, unlike the other pages Momentum favours expertise equally with celebrity.

Use of media sources and external content

Momentum's approach to media sources during the 2017 General Election is relatively reflective of the other Labour pages, with a few unique approaches that set the organisation apart. Momentum, like the other Labour pages did not use news media links; Labour were interested in keeping audiences on Facebook except for specific participatory purposes. Examining mainstream media use, Momentum utilise media content but only if it can be edited. Momentum's use of positive and negative mainstream media (positive $12 \%$, negative $14 \%$ ) is found at rates very similar to the leader page (positive $13 \%$, negative $13 \%)$, in contrast, the party page did not use mainstream media content $(0 \%$ positive, 5\% negative). During the election Momentum used mainstream media 
creatively. The group used many different types of mainstream content to promote or attack politicians and leaders in novel ways. Examples include editing images of The Office alongside Theresa May, the use of Question Time or news interviews. The group used a novel approach, because as Dennis notes, Momentum was "operating outside of the restrictions of formal party politics" (2019: 110). Momentum was free to communicate in a different way to the other pages.

Outside of mainstream media use, Momentum was the only page interested in promoting the party's campaign success via polling content $(6 \%)$. This occurred centrally via Twitter screen captures. A fundamental area of difference is seen in the groups use of alternative media, Momentum used alternative media positively $(6 \%)$, while the other Labour pages did not. For Momentum, alternative media sources included YouTube videos of Novara Media and the Artist Taxi Driver, as well as Skwawkbox news content. One of the benefits for Momentum over Labour, is because it is not an official page it can use an informal style and sources outside of the mainstream. This allows Momentum to tap into a vast array of left-wing bloggers, YouTubers and partisan news, that the other more establishment pages distance themselves from. This gap gave Labour the capacity to campaign both as a radical outsider, as well as maintain a sense of official competency.

Examining the use of external content, across the 2017 election, Momentum were keener to reuse content than the other Labour pages, including positive and negative use of external content. $42 \%$ of Momentum's election content reused external content, as opposed to $24 \%$ of Corbyn's content and only $3 \%$ of Labour Party page content. Momentum used the platform to energise support via recasting and reacting to the news of the day, with a bonus being that news media provides a cheap, consistent and easy source of content. Given reduced staff and funds, Momentum sought easy sources of content for the page. Overall, the Labour Party was selective in how each page used media content. Momentum, and to a lesser extent Corbyn's page, are there to fit their campaigns 
into a more aggressive news-orientated environment, while the Labour Party page continued with its focus on policy information.

Sentiment and framing

Momentum has been labelled a radical element within the Labour Party, with some commentators referring to it as a negative force. However, across the 2017 campaign Momentum was generally positive ( $71 \%)$, with the group more positive than the leader page (61\%) although not as positive as the party page (88\%). The group utilised levels of negativity (47\%) similar to the leader page (44\%) but was far more negative than the party page (29\%). Momentum clearly utilised sentiment more strongly than the other pages, with content tending towards sentiment extremes. However, the page was only similar in sentiment to Corbyn's page, the idea that the group framed content in a more extreme manner during the election campaign is not visible.

Examining approaches to problems and solutions, across the 2017 election, Momentum's use of pledges was small compared to the other pages (10\% Momentum, $66 \%$ party page), reflecting a low interest in policy content. Momentum's diagnosis of success was higher (27\% Momentum, $15 \%$ leader, $21 \%$ party page), while use of how we solve problems was lower (52\% Momentum, $90 \%$ party page). In most other aspects Momentum was clearly used in a similar way to the other pages, for example, Momentum utilised diagnosis content at rates $(92 \%)$ akin to the party page $(90 \%)$.

Although slightly more radical in its framing than the other pages, Momentum was still clearly centred on the public during the election campaign. Content was designed to cause reaction and influence people's broader political discussions and positions, but not be so radical as to become insular and incapable of spreading. 
Momentum features incredibly short text messages, while videos are conversely rather long. This is because the organisation used several long Facebook Live videos in 2017, these included training videos of how to campaign on the doorstep, a 2-hour promotion of registering to vote and a long-form interview with Corbyn. Momentum's use of Facebook Live to organise and teach virtual members is a truly novel application of social media to an election campaign. It points to the interesting approaches the group takes towards activism online and offline. Excluding these longer approaches Momentum's video length is like the other Labour pages, shorter videos are becoming the norm.

Use of personalisation

As a group founded to support Corbyn and his politics, Momentum understandably heavily featured Corbyn in 2017, 36\% of Momentum content praised Corbyn in contrast to $15 \%$ for the party page. Momentum had an explicit goal of promoting the leader, with Corbyn featuring in nearly as many videos via Momentum $(30 \%)$ as via his own leader page (38\%). Corbyn was also consistently referenced in the small amount of text Momentum content featured (16\%). The former Labour leader appears front and centre in Momentum's campaign, with the group clearly a satellite of Corbyn rather than the Labour Party page.

Momentum's criticism of political leaders was not just political but also included attacks on personality. For example, Theresa May was attacked for being like Alan Partridge and thus uncool. Momentum charged their negative leadership content with personalised antagonistic criticisms, rather than the more purely political nature of Corbyn or the party page's criticisms. Thus, although all the Labour pages used negative 
personalisation, Momentum utilised the form with true hyperbolic venom. This approach was clearly a tactic to energise and activate virtual members and potential supporters.

While use of leaders is high, elements of true personalisation are lacking during election campaigns. Leaders are used as figureheads with genuine personality diminished. Momentum bucks this trend, as the groups rates of real personalisation are akin to Corbyn's page. The use of personal messages is high at $21 \%$ of 2017 content, compared to $13 \%$ of Corbyn's content. First-person language (46\%) was also high, with rates over double the party page (19\%) and even higher than Corbyn's page (40\%). Momentum used highly personalised language, offering ownership to the viewer in the way information and ideas are discussed. Further, when leaders or politicians were used, they often spoke personally from the heart. Momentum's personalisation approach presented a more genuine face to the public, without the hinderance of stultifying professionalism or traditional rhetoric. Personalised informal communications were a clear set style of Momentum's attempts to reach out to a wider body of Facebook users. In examining the use of party and opposition politicians during the 2017 General Election, Momentum uses Labour's wider base of politicians at similar rates to Corbyn's page. Rates are relatively low, with it clear that Facebook is a platform primarily used for the promotion of leaders not party politicians.

Use of humour and rhetorical tools

Humour was underutilised by the party and leader pages during the 2017 General Election; this is not the case with Momentum. $25 \%$ of all the content sent by Momentum in 2017 featured some form of humour, this contrasts with only $3 \%$ for the Labour Party page and $7 \%$ for Corbyn. The humour used was broader, as it encompassed meme, general and political humour at high rates. As such humour was used to broaden the potential 
reach of political information, as political humour was often merged with meme style humour. For example, in Set 1 a screen cap of a video entitled 'Theresa May is just like Alan Partridge' can be seen. Video's such as these melded pop culture and politics together and were very popular. The most popular Momentum video entitled 'Tory Britain 2030' with the by-line 'Brutal response (-) (wait for it)', received 13,000,000 views and well over 100,000 shares ${ }^{2}$. Through these humorous video's Momentum achieved true virality while also pushing political messages. The use of humour clearly shows Momentum was trying to reach a different audience in a different way, fulfilling a role Corbyn or the party page could not.

The use of meme style humour, an approach not seen in the party or leader page's, shows the unique way Momentum was communicating and who they were trying to reach. Momentum adopted the internet style of meme pages seen on Facebook, with their communications mirroring popular pages such as Lad Bible. As Dennis argues, Momentum "draws on a youthful, digitally-enabled civic vernacular that exists online. Whereas party political campaigning online often replicates professional norms refined across other media (Lilleker et al., 2016), Momentum embraces the humour and irony that typifies the social web" (Dennis, 2019, p.98). Momentum was aping a stylistic approach designed to engage younger heavy social media users.

Momentum also utilised a large array of rhetorical tools; however, rates of use were generally far below the other party pages. Party catch phrase use was particularly minimal (6\%), showing how Momentum is a force apart from the official party and leader pages, where use was particularly common (69\% leader, $80 \%$ party page). Repetition is seen $(29 \%)$ with use higher than the party $(22 \%)$, but lower than the leader page (44\%),

\footnotetext{
${ }^{2}$ https://www.facebook.com/watch/?v=459077241104335 - accessed 20/10/2019
} 
us versus them rhetoric is also favoured (24\%) but again is seen less than both leader $(39 \%)$ and party pages (38\%). The lack of rhetorical tools is in part due to Momentum's style, text is fleeting with the organisation utilising a straightforward seemingly nonpolitical approach favouring brevity over rhetoric. This rejection of traditional rhetoric is further seen in the utilisation of other communications forms. Emoji's are common, as is slang and informal language.

Use of partisanship

Labour focuses on depiction; this extends to the depiction of party activists and members with Momentum also using the form. The data shows that across Momentum's 2017 election posts, $20 \%$ of post in-text elements featured ordinary party members. However, use was not much higher than the other pages (17\% leader, $16 \%$ party page). Momentum, like the other party pages, was more interested in representing the general public rather than members during the 2017 campaign. Reflecting earlier findings that Momentum is less interested in identity issues than one may expect, use of minority party members was seen less via Momentum (9\%) than the other pages (16\% party page, $12 \%$ leader). The only instance in which Momentum tried harder to represent membership diversity was via their depiction of minority Labour politicians (2\%). Overall, during the election Momentum are shown to be interested in party member depiction at rates like the other Labour pages. Examining 2017 election approaches to praise and negativity, use of praise is very stable across the pages. Momentum generally follows the leader and party page in praising campaigners, members and certain MP's. However, the different Labour pages supported very diverse types of MP's. Momentum put great effort into supporting left-wing pro-Corbyn MP's such as Rebecca Long-Bailey. In contrast, the Labour Party page focused on certain core shadow Cabinet members like John Ashworth; while 
Corbyn's page focused on important politically allied politicians like John McDonnell and Diane Abbott. The different pages optimised their use of MP's for their intended audience.

In the negative use of opposition MP's Momentum's use (5\%) was higher than the party page (3\%), but reflective of the leader page's approach $(6 \%)$. One area of interest was Momentum's negative appraisal of Tony Blair, with $1 \%$ of content during the election campaign negative about the previous Labour Prime Minister. This internal partisanship shows that the political battle within Labour was not totally called off during the election campaign, with Blair negatively used by Momentum to activate virtual members and potential voters. Overall, Labour ran a positive campaign in terms of generating partisan sentiment, any negativity against the opposition centred on the use of opposition leaders, not politicians or party members.

Overall, Momentum focused on partisanship and praise to a similar degree to the other Labour pages during the election campaign. The page like the others was clearly focused on reaching outside their own membership or virtual members. In contrast, Momentum's approach shifted post-election, the group refocused on internal campaigns and were happy to train their guns on the right-wing of the party itself. Momentum's success in the \#JC9 campaign showed how they energised their supporters. This success from internal satellite campaigning clearly highlights the power of movement groups to successfully alter a wider party's politics.

Use of links

Within Labour during the 2017 election campaign, party websites were not heavily pushed by either the leader $(15 \%)$ or party page $(12 \%)$. Momentum breaks this trend as they heavily pushed their party websites (53\%), they were focussed on activating and 
organising their online support. Momentum promoted participation extensively, with the group happy for users to be guided off their Facebook content onto party websites. This is because a core goal was participation not just information. In contrast to the use of party websites, Momentum used lower rates of calls to visit other websites (5\%), than the party $(12 \%)$ or leader page $(15 \%)$. The central reason is because Momentum did not extensively link the UK Government's register to vote website. The registration drive was mainly seen via the party and leader websites. The lack of this registration drive is because Momentum's approach was dualistic, the page centred on informing the broader public as well as activating their virtual members, a group who given they are politically interested are more likely to be registered. Finally, the use of calls to visit other mediums and social media networks were not seen.

In external links and internal links, used by the pages, it is important to note that some of the difference is because Momentum would often not provide a physical link to the web-location they pushed a user to visit. Examining external links, 31\% of 2017 Momentum content linked to a party webpage, much higher than the party (12\%) and leader page (3\%). While, in contrast external webpage links were lower (6\%) compared to the party (12\%) and leader page (14\%). Novel use of hashtags is more readily seen via Momentum, 16\% of Momentum's 2017 content used the form, more than Corbyn (10\%) or the party page $(2 \%)$. The use of hashtags speaks to how Momentum was more up to date with communication tools, as use allowed Momentum to tie in Twitter and wider internet trends with their Facebook content. No links were seen to Instagram or YouTube, if YouTube content was used it was reissued via Facebook video. Examining internal links during the 2017 General Election. Momentum did not extensively link to any party Facebook page (8\%), with rates like the party page (12\%) but far below Corbyn's page (31\%). Momentum was more self-isolated within the wider Facebook Labour network. Momentum, if it did internally link, linked to other non-Labour Facebook pages, these 
included people such as Owen Jones or celebrities such as Stormzy.

Use of data gathering tools

Data gathering practises were slightly lower via Momentum (9\%) than for the leader page $(15 \%)$, but higher when compared to the party page $(5 \%)$. Momentum was clearly interested in gathering information from supporters, however this was mostly location information, because Momentum's tool 'mynearestmarginal.com' pushed users for location ID. The data shows that Momentum was driving individuals to their websites for other functions such as organisation, rather than for data gathering. Overall, it appears Labour centrally used Corbyn to gather data, with this a smart move because of the huge array of new support the leader brought in.

\section{$\underline{\text { Participation }}$}

Voting

As suggested earlier from the lack of external links, during the 2017 campaign Momentum was much less concerned with getting people to register to vote $(3 \%)$, than the party $(14 \%)$ or leader $(11 \%)$ page. Momentum's limited voter registration efforts were centrally targeted at younger people, rather than the general approach seen via the other Labour pages. Instead of voter registration, Momentum concentrated on participation via getting viewers to visit campaign pages. The group showed a focus on a different class of audience than the party and leader page. Rather than the less likely registered, less politically attentive mass public; Momentum was centrally targeting both a wider band of the politically interested radical public, alongside virtual members. Overall, $47 \%$ of 2017 content prompted users to visit campaign pages including 'mynearestmarginal.com' and 'Momentum.org'. In contrast, only 3\% for the leader and 12\% for the party page did the 
same function. These pages, especially 'mynearestmarginal', engaged in open ended 'just turn up' style electoral participation, promoting doorstep campaigning within important marginal seats. Momentum was clearly utilising a more fluid structure towards participation and organisation, showing some elements of what Margetts labelled the Cyber Party (2001).

Examining calling for votes. Momentum across the 2017 election was very much trying to reach a broad, but clearly more partisan, audience than the other Labour pages. Although Momentum did call for votes (12\% in 2017), usage was well below the party $(85 \%)$ and leader page $(60 \%)$. The group was clearly not part of the traditional Facebook campaign, but was orientated as much around participation as novel approaches to information. Though Momentum was still trying to speak to a broad audience, it was clearly not as broad as the other Labour pages and far more partisan and politically engaged.

Other participation forms

Other online forms of participation were also popular across the election. Momentum's 2017 campaign use of other approaches to online participation (7\% total), was much higher than the other Labour pages ( $1 \%$ total). In terms of Momentum's focus, although signing petitions (1\%) and a shop (1\%) saw minimal use, funding was a clear area of interest (5\%). Momentum was trying to monetarily capitalise on its newfound online support. This use of crowdfunding during an election campaign is novel, most groups gather resources before a campaign starts. The approach worked however, as the 
group raised $£ 260,000$ across the one-month campaign ${ }^{3}$. Alongside a strong interest in pushing online forms of participation through Facebook activities and party websites, Momentum placed a huge amount of effort in getting supporters to volunteer and campaign offline. The data shows that during the 2017 General Election, Momentum was trying to use their virtual members and the wider public as offline activists. High rates of content pushed virtual members and viewers to help doorstep campaign (48\%), volunteer (49\%) and sign up to campaign (42\%). Momentum's rates of participation content were considerably higher than the other Labour pages, for example $49 \%$ of Momentum's content pushed for volunteering, vastly higher than the leader $(2 \%)$ or party page $(7 \%)$. Although much of this volunteering was filtered through Momentum's websites, thus showing a more traditional style of organisation. Participation was also directly generated via Facebook. Events and protests were encouraged ( $2 \%$ total), while organic information dissemination was promoted through asking users to talk to their friends and family (10\%). This was also seen via Corbyn's page $(6 \%)$, but much less commonly via the party page (2\%). Momentum clearly believed in the power of individuals' organic communications and the sociological model. A major example of this tactic was the group's efforts in asking supporters to 'talk to your grandparents', pushing virtual members to phone up their family and persuade them of the importance of a Labour government. Momentum clearly threw itself into the idea that you can mobilise online support and break outside the echo-chamber, through utilising the genuine social networks individuals have.

${ }^{3}$ https://www.theguardian.com/politics/2019/nov/04/labours-momentum-raises-250000-in-sixdays-to-fight-election accessed 08/06/2020 
Engagement

Examining Momentum across the 2017 election, the promotion of sharing is also popular. $32 \%$ of Momentum content pushed users to share, as opposed to $59 \%$ for the party, and only $8 \%$ for the leader page. Over time blanket calls to share are declining, it is possible that the Labour Party is experimenting using Corbyn's page without the form. Given that the leader page receives far more engagement, the use of prompts for engagement may appear unnecessary, with page operators intending to maximise engagement via not using traditional style calls to engagement.

Across all the Labour pages' engagement is shown to clearly be important. Labour in 2017 appreciated that the right sort of content, spread through the right sort of users, can get into important socio-demographic and cultural networks. This is a system that is not easily replicable through other tools. For more internet savvy audiences, e.g. via Momentum and Corbyn's page's, engagement was less heavily pushed. While for more traditional Facebook content engagement was summarily prompted. Overall, engagement was used by Labour in a nuanced and subtle manner depending on page and audience. Labour pushed consistent (but undramatic) engagement via the party page, the leader page did not push engagement as it would appear impersonal, while Momentum engaged in a more speculative approach that sometimes led to impressive virality. Momentum wanted engagement but used pushes for engagement selectively, not at the risk of appearing demanding, obscuring the impact of content or looking impersonal.

\section{What role does Momentum play in Labour's Facebook campaign?}

Research question two asked the role Momentum has for Labour's campaign. Examining the 2017 General Election, Momentum clearly had a differentiated style, intended audience and political goal to the other Labour pages. Momentum evidently 
fulfilled a specific role, with approach informed by the core goals of the group, and what it could offer to the wider Labour campaign. Through supporting the leader, promoting broad novel political information and focussing on participation and organisation, Momentum offered to the Labour campaign something that was not available before. Dennis notes that; "Momentum replicates some of the organizing and campaigning practices of political parties... and draws on the organizational practices and modes of engagement associated with social movements..." (2019, p.110). However, as this paper has shown, Momentum does more than just replicate the organizing and campaigning practices of political parties. The group goes much further than the other party pages, showing a genuine interest in the power of social media to change political campaigning. Momentum may draw on the 'organizing and campaigning practices of political parties', but as is seen, through utilising novel approaches the group is taking these elements further than the other party pages.

Across information the page was less focussed on policy and political detail, instead the organisation focussed on broader political ideas, harnessing areas of major ideological cleavage. Momentum activated ideas not policy detail, using experts and celebrities to inform groups who were looking for more spirited political campaign discourse. Momentum was clearly trying to activate its own support, alongside left-wing partisans and young people. As Fraser Watt, a campaigns officer for London Young Labour asserted in 2017, "Labour appealed to a generation that came of age during the financial crisis" (Savage and Hacillo 2017). Momentum was also targeting people who had been pushed away by Labour's previously centrist position, utilising a political platform and style that appeared anti-establishment and as far away from New Labour as possible. As Dennis notes, Momentum has worked hard to "position the organization as outsiders (see Watts and Bale 2019), as they are simultaneously distinct from the norms and practices of Westminster politics but also dissimilar to competing factions" (2019: 
109). Overall, Momentum was clearly not targeting everyone, with their approach engaging, through virtual members, a wider group of the politically interested, who then in turn managed to reach the less politically interested. The groups viral success came organically from a combination of good content reaching the right initial, secondary and then tertiary audience.

Emma Rees, national organiser for Momentum stated in 2017, “we're out engaging ordinary people, making politics feel like... not politics. It's something the Tories could never replicate" (Rees: 2017). Momentum's humorous, frivolous approach using a language heavy internet-users understood, led to Momentum reaching a different audience. As Adam Klug, one of the Momentum's central team asserts, "we way beyond our own bubble - we only have 24,000 members"4. McDowell-Naylor argues this more fluid 'deterritorialization' approach was important to Momentum's success, as they could avoid the baggage of party bureaucracy (McDowell-Naylor: 2019). Indeed, through content designed to energise a broader partisan group that subsequently gained traction, Momentum achieved impressive virality. The group displayed the power of Facebook engagement, as well as the sociological nature of the platform, breaking across many barriers. From a small core of under 300,000 virtual members, in the "last week of the campaign over 1 in 3 Facebook users in the UK watched an entire Momentum video. With the best performing video, 'Tory Britain 2020', reaching 5.4 million views in just two days" (Momentum website 20195). Thus, Momentum not only went viral to heavy internet users but also within the broader Facebook public. Momentum shows that consistent,

\footnotetext{
${ }^{4}$ https://www.theweek.co.uk/general-election-2017/85501/how-momentum-helped-sway-thegeneral-election accessed 21/10/2019

${ }^{5}$ https://peoplesmomentum.com/2018/01/12/2017-general-election/ accessed 21/10/2019
} 
negative, impactful and emotionally resonant messaging can spread unabated across a Facebook network population. Momentum's information was hard to ignore, thus it subsequently reached voters across age, class, geography and political affiliation.

Participation approaches showed the group wanted to activate virtual members and the broader public. Margetts' (2001) cyber party model was clearly apparent. Whereas the other pages pushed traditional avenues of political participation. Momentum used Facebook as a source of human resources without interest in presenting hoops for potential activists to jump through. From heavily pushing Facebook users to visit Momentum websites, to online training sessions and pushes to organise online. Momentum struck a very different approach to the other party pages. Little interest was shown in Momentum enforcing membership or any systemic approach to the utilisation of virtual supporters offline. Instead the group enacted a 'just turn up' policy. This approach was in part adopted from the USA, as Bernie Sanders campaign was actively copied by Momentum (Rhodes 2019). The organisation was helped through direct advice from key Sanders campaign figures; Grayson Lookner, Jeremy Parkin, Kim McMurray and Erika Uyterhoeven. these figures were brought in "to give advice in activist training sessions, focusing on sending activists to the right places and ensuring people turned out" (Savage and Hacillo 2017).

Momentum's copying of Sanders campaign was dualistic. Penney states, “while the "official" Sanders organization-built applications to transform supporters into a tightly controlled distribution network for its social media messaging, this was complemented by "unofficial" grassroots networks that circulated more informal and culturally oriented appeals" via "self-organized connective action in digital social movements" (2017: 402). Similarly, Momentum utilised both semi-official tools such as mynearestmaginal.com and the Momentum App, as well as engendering 'just turn up' Facebook delivered participation. Overall, Momentum's online activity via Facebook was effective, 
"volunteers signed up online to help and were dispatched to nearby marginal seats" (Savage and Hacillo, 2017). 100,000 people used the 'mynearestmarginal' app to canvass in key marginal seats (Momentum website $2019^{6}$ ). As Tariq Parkes, activist and branch secretary in Hastings and Rye said, "we had 10 times more activists than in $2015 \ldots$ Momentum activists were at the college and the university - signing people up left, right and centre" (Savage and Hacillo 2017). These offline activities are on top of other successes in online activation, such as in funding or in talking to friends and family. Momentum's efforts for organic participation online and offline led to real results.

Facebook has offered parties new avenues for their communications that were previously not available, with the implications of this impacting on the parties themselves. Overall, Momentum as a satellite campaign offered the Labour Party a source for new volunteers, a viral engaging source for information delivery and the capacity to reach different audiences. Table 12 overleaf outlines a comparison using the findings of this paper, it clearly summarises the differences between the pages, and thus the exact function of the Momentum satellite campaign.

\footnotetext{
${ }^{6}$ https://peoplesmomentum.com/2018/01/12/2017-general-election/ accessed 21/10/2019
} 
Table 12. Central approaches of the pages

\begin{tabular}{|c|c|c|c|c|c|c|}
\hline \multirow{2}{*}{$\begin{array}{l}\text { Approach } \\
\text { Content structure }\end{array}$} & \multirow{2}{*}{$\begin{array}{l}\text { Labour Party page } \\
\text { Video }\end{array}$} & \multicolumn{3}{|c|}{ Labour Leader page } & \multicolumn{2}{|c|}{ Momentum page } \\
\hline & & Video & Photo & Link & Video & Photo \\
\hline Structural forms & Infographics & $\begin{array}{l}\text { Mainstream } \\
\text { media }\end{array}$ & Posters & Government website & Mainstream media & Twitter, memes \\
\hline $\begin{array}{l}\text { Topic choice } \\
\text { frequency }\end{array}$ & High topic frequency & \multicolumn{3}{|c|}{ Medium topic frequency } & \multicolumn{2}{|c|}{ Medium topic frequency } \\
\hline $\begin{array}{l}\text { Topic choice } \\
\text { diversity }\end{array}$ & $\begin{array}{l}\text { Specific focus on economy, health and social } \\
\text { care, party action }\end{array}$ & \multicolumn{3}{|c|}{$\begin{array}{l}\text { Broad focus but core approached towards economy, } \\
\text { protection, health and social care, party action, } \\
\text { leadership }\end{array}$} & \multicolumn{2}{|c|}{$\begin{array}{l}\text { Specific focus on economy, protection, party } \\
\text { action, leadership }\end{array}$} \\
\hline $\begin{array}{l}\text { Policy detail and } \\
\text { political information }\end{array}$ & $\begin{array}{l}\text { High policy detail } \\
\text { High levels of positive political information } \\
\text { High mixed sentiment, use of position issues }\end{array}$ & \multicolumn{3}{|c|}{$\begin{array}{l}\text { Medium policy detail } \\
\text { Negative mixed sentiment political information } \\
\text { Low position issue use }\end{array}$} & \multicolumn{2}{|c|}{$\begin{array}{l}\text { Low policy detail } \\
\text { Negative mixed sentiment political information } \\
\text { Medium negative use of position issues }\end{array}$} \\
\hline $\begin{array}{l}\text { Expertise and } \\
\text { celebrity }\end{array}$ & $\begin{array}{l}\text { Celebrity over expertise } \\
\text { High celebrity use, low expertise use }\end{array}$ & \multicolumn{3}{|c|}{$\begin{array}{l}\text { Celebrity over expertise } \\
\text { High celebrity use, low expertise use }\end{array}$} & \multicolumn{2}{|c|}{$\begin{array}{l}\text { Expertise over celebrity } \\
\text { High use of both }\end{array}$} \\
\hline News media use & $\begin{array}{l}\text { Low negative mainstream media use } \\
\text { Low reuse of external content }\end{array}$ & \multicolumn{3}{|c|}{$\begin{array}{l}\text { Medium mainstream media use equally positive and } \\
\text { negative } \\
\text { Use of newspaper sources and newspaper sources } \\
\text { via link } \\
\text { Medium reuse of external content }\end{array}$} & \multicolumn{2}{|c|}{$\begin{array}{l}\text { Medium mainstream media use, equally positive } \\
\text { and negative } \\
\text { Use of alternative media, polling } \\
\text { High reuse of external content }\end{array}$} \\
\hline Depiction & $\begin{array}{l}\text { Use of women's issues and depiction } \\
\text { Low interest in minority depiction } \\
\text { Balanced depiction of all age groups and } \\
\text { issues associated especially the young } \\
\text { Low use of general public's voice } \\
\text { High use of public and relevant workers }\end{array}$ & \multicolumn{3}{|c|}{$\begin{array}{l}\text { Low interest in women's issues and minority } \\
\text { depiction, } \\
\text { Depiction of all age groups and issues associated but } \\
\text { focus on young and old people } \\
\text { Low use of general public's voice } \\
\text { High use of ordinary public and relevant workers }\end{array}$} & \multicolumn{2}{|c|}{$\begin{array}{l}\text { Low interest in women's issues and minority } \\
\text { depiction } \\
\text { Depiction of all age groups and issues associated } \\
\text { but focus on young, middle-aged and children } \\
\text { High use of general public's voice and relevant } \\
\text { workers, but low use of ordinary public }\end{array}$} \\
\hline Framing & $\begin{array}{l}\text { More neutral than other pages, more positive } \\
\text { than negative } \\
\text { High focus on pledges, diagnosis, prognosis } \\
\text { and motivation }\end{array}$ & \multicolumn{3}{|c|}{$\begin{array}{l}\text { Mixed, equally negative and positive } \\
\text { High focus on pledges, diagnosis, prognosis and } \\
\text { motivation Short videos, long messages }\end{array}$} & \multicolumn{2}{|c|}{$\begin{array}{l}\text { Bipolar, very positive and negative } \\
\text { High focus on diagnosis and prognosis, low } \\
\text { motivation content } \\
\text { Long videos, short messages }\end{array}$} \\
\hline
\end{tabular}




\begin{tabular}{|c|c|c|c|}
\hline & Short videos, medium length messages & & \\
\hline $\begin{array}{l}\text { Personalisation, } \\
\text { rhetoric, and } \\
\text { humour }\end{array}$ & $\begin{array}{l}\text { Some praise of leader, low use of Corbyn in } \\
\text { content } \\
\text { Low use of opposition leader, low negative } \\
\text { appraisal of opposition, } \\
\text { Low personalised language } \\
\text { Low use of humour } \\
\text { High use of rhetorical tools especially us } \\
\text { versus them rhetoric, catch phrase, three-part } \\
\text { lists, questions and repetition }\end{array}$ & $\begin{array}{l}\text { Low praise of Corbyn, high use of leader in video, } \\
\text { imagery and text } \\
\text { High use of opposition leader, high negative } \\
\text { appraisal of opposition } \\
\text { High personalised language } \\
\text { Low use of humour } \\
\text { Medium use of rhetorical tools especially us versus } \\
\text { them rhetoric, catch phrase and repetition }\end{array}$ & $\begin{array}{l}\text { High praise of Corbyn, high use of leader in } \\
\text { video, imagery and text } \\
\text { High use of opposition leader, high negative } \\
\text { appraisal of opposition } \\
\text { High personalised language } \\
\text { High use of humour } \\
\text { Low use of rhetorical tools especially repetition } \\
\text { and us versus them rhetoric }\end{array}$ \\
\hline Links & $\begin{array}{l}\text { Medium calls to visit party website } \\
\text { Medium calls to visit other websites } \\
\text { Medium party website links } \\
\text { Low use of hashtags } \\
\text { Low data gathering } \\
\text { Medium party internal links, low opposition } \\
\text { internal links } \\
\text { Low links to other Facebook pages }\end{array}$ & $\begin{array}{l}\text { Low calls to visit party website } \\
\text { Medium calls to visit other websites } \\
\text { Low party website links } \\
\text { Medium use of hashtags } \\
\text { Medium data gathering } \\
\text { High party internal links, high opposition internal } \\
\text { links } \\
\text { High links to other Facebook pages }\end{array}$ & $\begin{array}{l}\text { High calls to visit party website } \\
\text { Low calls to visit other websites } \\
\text { High party website links } \\
\text { Medium use of hashtags } \\
\text { Low data gathering } \\
\text { Low party internal links, low opposition internal } \\
\text { links } \\
\text { High links to other Facebook pages }\end{array}$ \\
\hline Partisanship & $\begin{array}{l}\text { Medium use of party members } \\
\text { High use of minority party members } \\
\text { Medium praise of campaigners }\end{array}$ & $\begin{array}{l}\text { Medium use of party members } \\
\text { Medium use of minority party members } \\
\text { Medium praise of campaigners }\end{array}$ & $\begin{array}{l}\text { High use of party members } \\
\text { Low use of minority party members } \\
\text { High praise of campaigners } \\
\text { Negative appraisal of same party leaders/MP's }\end{array}$ \\
\hline $\begin{array}{l}\text { Participatory } \\
\text { practices }\end{array}$ & $\begin{array}{l}\text { Medium register to vote } \\
\text { Low visit campaign page } \\
\text { No other forms of online participation } \\
\text { Low talk to friends } \\
\text { High call for vote } \\
\text { Low call to join party }\end{array}$ & $\begin{array}{l}\text { Medium register to vote } \\
\text { Low visit campaign page } \\
\text { No other forms of online participation } \\
\text { Medium talk to friends } \\
\text { Medium call for vote } \\
\text { Low call to join party }\end{array}$ & $\begin{array}{l}\text { Low register to vote } \\
\text { High visit campaign page } \\
\text { Low other forms of online participation, polls, } \\
\text { petitions, shop, medium calls for funding } \\
\text { High help doorstep campaign, volunteer and } \\
\text { sign-up, Medium talk to friends } \\
\text { Low call for vote or to join party }\end{array}$ \\
\hline Engagement & $\begin{array}{l}\text { Low interest in engagement } \\
\text { High promotion of sharing }\end{array}$ & $\begin{array}{l}\text { Low interest in engagement } \\
\text { Low promotion of sharing }\end{array}$ & $\begin{array}{l}\text { Low interest in engagement } \\
\text { Medium promotion of sharing }\end{array}$ \\
\hline
\end{tabular}




\section{Is Labour engaged in Janus-Faced campaigning?}

Research question three asked; was Labour engaged in Janus-faced campaigning? Labour was utilising both a traditional Facebook campaign, as well as a new methods campaign. Labour's approach to Facebook showed capacities for both "controlled interactivity" (Freelon 2017) as seen via the Labour Party page, and "self-organised movements" (Penney 2017) as seen via Momentum. Across the two pages that made up the traditional Facebook campaign. The Labour Party page was the positive 'official' professionalised presence of the party on Facebook, it focussed on detailed political information of a core array of electorally important topics. The page was designed for the public, linking mainly to government and party websites, using catch phrases, celebrity over expertise, and focusing on infographic videos. The page focussed on information over participation, depictions of the public and fact over emotion, with any focus on participation surrounding the act of voting and registering to vote.

Within the traditional Facebook campaign, across the leader page element, Jeremy Corbyn's page was a mixed sentiment leadership vehicle for a more radical and emotional version of the party page's politics. Both negative and positive, and often targeting opposition leaders. The page focused on a broader array of political topics, through more varied structural approaches that featured less political detail but used more emotion and personalised communication. The page was designed to activate the public, using celebrities over expertise, public depiction, mainstream media content and a focus on information over participation. Internal links were common, while participation was focussed towards voting and registering to vote. Corbyn was vital to both his personal page and Momentum's campaign, as Matt Zarb-Cousin, Corbyn's former spokesman stated, "he was much more recognised as an opposition leader than Ed Miliband" (Savage and Hacillo 2017). 
Outside of the traditional Facebook campaign, we saw Labour utilising new methods through its satellite campaign Momentum. Momentum's page was designed for a combination of core virtual members and the radical public. An innovative vehicle for participation, the group pushed for fluid, barrier free, online and offline participation. Their approach to information was emotive, humorous and deliberately lacked detail, content was often video based, mixed in sentiment, using attacks on opposition and even its own party. This promoted user engagement and virality. Focussing on a few core areas especially leadership and party action, political information was ideological and general, but used expertise over celebrity. Partisanship was pushed and campaigners praised, with the page splitting from Labour's recent past to speak successfully to a new audience of younger people. Keen to use the public as its voice when using its own narrative, Momentum used an 'internet style' in its communications.

Momentum offered Labour many benefits. One of the major ones is a new resource for activists. As Dommett and Temple contend; "Enos and Hersh's work (2015) has shown parties' reliance on members that are unrepresentative of the general public can prove counterproductive in attempts to campaign" (2018: 198). Momentum through its more fluid approach to activism, offered to the Labour campaign a new online and offline resource that could be harnessed. These younger individuals were also more diverse and active online, capable of appreciating how to help content go viral, and more technologically competent than average Labour activists. Momentum also offered innovation. As Dommett and Temple assert, satellite campaigns are "organisations less restricted by legal requirements and responsibilities, these bodies have the space to innovate and trial new tools that parties may be wary of promoting" (2018: 196). Momentum were radical, using humour and a less serious nature to create engaging content, they could use less stringent sources and campaign more around ideas than policies. This offered Labour fluidity in the messages they could be sending, as they already had policy covered by the party page, and leadership covered by 
Corbyn's page.

Overall, Labour ran a successful 2017 General Election campaign, “...people felt Labour's message was authentic and speaking to them and their lives. You see that in things like the polling on what policies people recall - they recalled positive offers from the Labour party and negative things about the Conservatives" - Labour campaign source, $2017^{7}$. Part of this was because Labour was communicating to people via Facebook through varied and appropriate ways. Labour was using different pages with different approaches to reach different audiences, presenting different faces of the same political party to the public. With the successful implementation of this strategy likely at the centre of Labour's 2017 campaign success. While their failure to utilise the same system as effectively in 2019 appears a likely part of their failure. This will need to be studied in detail, with it clear that in 2017, Labour was using Momentum, the party and leader pages in different ways for different purposes. Table 13 outlines Labour's approach to Janus-faced campaigning via the party, leader and Momentum pages. It is vital we appreciate this new phenomenon. This is because the evidence suggests that campaigning is not blending particularly between offline and online, or through traditional and new media forms (as per Chadwick 2013). Instead, Facebook campaigns are becoming more distinct from other approaches, with greater internal complexity.

Satellite campaigns and Janus-faced campaigning are core approaches to how parties are using Facebook. Although multi-faceted approaches are not revolutionary, their use via Facebook represents an evolutionary leap in how parties are campaigning on the platform. Momentum are revealing the future direction of campaigns, because they clearly engage with the idea that online activity can lead to offline action. Lines were blurred between online

\footnotetext{
${ }^{7}$ https://www.theguardian.com/politics/2017/jun/10/jeremy-corbyn-youth-surge-votes-digitalactivists accessed 21/10/2019
} 
activism and offline action, with the party interested in more fluid conceptions of membership and how to run a political campaign. At the edges of the Labour campaign we are therefore seeing the rise of new methods in Facebook use, as well as the lines of distinction between online and offline campaigning being blurred. As such, further study of Momentum must occur given they are altering how Facebook is used as a campaign tool. 
Table 13. 2017 General Election Labour party-controlled Janus-faced campaigning of three core pages

\begin{tabular}{|c|c|c|c|}
\hline \multirow{3}{*}{$\begin{array}{c}\text { Theme } \\
\text { Page type }\end{array}$} & \multicolumn{3}{|c|}{ Party controlled } \\
\hline & \multicolumn{2}{|c|}{ Traditional Facebook campaign } & New method example \\
\hline & Party Page & Leader Page & 'Party movement satellite campaign' \\
\hline Party Control & Central office control & Central office and leader office controlled & $\begin{array}{l}\text { Party-linked and influenced but operates via Momentum } \\
\text { offices }\end{array}$ \\
\hline Example & Labour Party Page & Jeremy Corbyn Page & Momentum Page \\
\hline Target audience & Public Facebook users & $\begin{array}{l}\text { Public Facebook users, virtual members and } \\
\text { supporters }\end{array}$ & Centrally virtual members and supporters but also public \\
\hline $\begin{array}{l}\text { Attitude to parent } \\
\text { organisation }\end{array}$ & Represents Labour officially & $\begin{array}{l}\text { Represents Labour officially, but represents } \\
\text { leader specifically }\end{array}$ & Internally partisan represents Labour left-wing \\
\hline $\begin{array}{l}\text { Information or } \\
\text { participation focus }\end{array}$ & Information & Information & Participation \\
\hline $\begin{array}{l}\text { Information } \\
\text { approach }\end{array}$ & $\begin{array}{l}\text { Broad public focus, focus on core important } \\
\text { policy and political information }\end{array}$ & $\begin{array}{l}\text { Broad public focus, focus on wide policy, core } \\
\text { policy and political information }\end{array}$ & $\begin{array}{l}\text { Mixed focus on public and supporters, focus on political } \\
\text { information but not on policy detail }\end{array}$ \\
\hline $\begin{array}{l}\text { Participation } \\
\text { approach }\end{array}$ & $\begin{array}{l}\text { Broad public focus - Focus on participation } \\
\text { as voting }\end{array}$ & $\begin{array}{l}\text { Broad public focus - Focus on participation as } \\
\text { attendance of events and as voting }\end{array}$ & $\begin{array}{c}\text { Narrow focus on virtual members - Focus on participation } \\
\text { via organising virtual members and official party members } \\
\text { to campaign offline }\end{array}$ \\
\hline Goal & $\begin{array}{l}\text { Promote Labour Party policy and ideas, win } \\
\text { elections for Labour }\end{array}$ & $\begin{array}{l}\text { Promote Labour Party policy and ideas, win } \\
\text { elections for Labour, promote Corbyn as leader }\end{array}$ & $\begin{array}{c}\text { Promote Momentum membership, Corbyn as leader and } \\
\text { the left of the Labour Party }\end{array}$ \\
\hline Professionalisation & $\begin{array}{l}\text { Is a professionalised entity using bespoke } \\
\text { content in a formal style }\end{array}$ & $\begin{array}{l}\text { Is a professionalised entity using bespoke } \\
\text { content in a formal style }\end{array}$ & $\begin{array}{c}\text { Is less professionalised entity, uses some bespoke content, } \\
\text { but also reissues others content, also utilises a less formal } \\
\text { approach including the use of an 'internet' style and } \\
\text { humour }\end{array}$ \\
\hline Sense of self & Formal party & Formal party leader & $\begin{array}{l}\text { Grassroots organisation viewed as a 'movement' with direct } \\
\text { relationship with the people }\end{array}$ \\
\hline Personalisation & Depersonalised, Corbyn absent & Corbyn heavily personalised and used & Corbyn heavily personalised and used \\
\hline Sources & $\begin{array}{l}\text { Labour website's, mainstream news via } \\
\text { video edited content }\end{array}$ & $\begin{array}{l}\text { Labour website's, mainstream news via video } \\
\text { edited content, news links }\end{array}$ & $\begin{array}{c}\text { Twitter screencaps, Momentum websites, mainstream and } \\
\text { alternative news }\end{array}$ \\
\hline Depiction & Uses public, activists and party politicians & Uses activists, public and leader & Uses activists, public and leader \\
\hline
\end{tabular}




\section{Notes}

Tristan Hotham holds a PhD from the University of Bath. His research focusses on campaigning, political communication and social networks. His work has been published in Election Analysis and the Observer [email@ t.hotham@bath.ac.uk].

\section{Acknowledgments}

No potential conflict of interest was reported by the authors.

\section{Funding}

Tristan Hotham received funding from the Economic and Social Research Council for this research.

\section{ORCID}

Tristan Hotham - https://orcid.org/0000-0003-4931-9349

\section{References}

- $\quad$ Alashri, S., Kandala, S.S., Bajaj, V., Ravi, R., Smith, K.L. and Desouza, K.C., 2016. An analysis of sentiments on Facebook during the 2016 US presidential election. 2016 IEEE/ACM International Conference on Advances in Social Networks Analysis and Mining (ASONAM). IEEE, pp.795-802.

- Anstead, N. and Chadwick, A., 2008. Parties, election campaigning, and the Internet: Toward a comparative institutional approach. Routledge handbook of internet politics. Routledge, pp.72-87.

- Bale, Tim, Webb, P. and Poletti, M., 2019a. Footsoldiers: Political Party Membership in the Twenty-First Century. Routledge.

- Bene, Márton, 2017a. Go viral on the Facebook! Interactions between candidates and followers on Facebook during the Hungarian general election campaign of 2014. Information, Communication \& Society, 20(4), pp.513-529.

- Boulianne, S., 2019. Revolution in the making? Social media effects across the globe. Information, communication \& society, 22(1), pp.39-54.

- Chadwick, A., 2017. The hybrid media system: Politics and power. Oxford University Press.

- Dennis, J. "A party within a party posing as a movement? Momentum as a movement faction." Journal of Information Technology \& Politics 17.2 (2020): 97-113. 
- Dommett, K. and Bakir, M.E., 2020. A Transparent Digital Election Campaign? The Insights and Significance of Political Advertising Archives for Debates on Electoral Regulation. Parliamentary Affairs, 73(Supplement_1), pp.208-224.

- Dommett, K. and Temple, L., 2018. Digital campaigning: The rise of Facebook and satellite campaigns. Parliamentary Affairs, 71(suppl_1), pp.189-202.

- Edwards, A., 2006. ICT strategies of democratic intermediaries: A view on the political system in the digital age. Information Polity, 11(2), pp.163-176.

- Enli, G., 2017. Twitter as arena for the authentic outsider: Exploring the social media campaigns of Trump and Clinton in the 2016 US presidential election. European journal of communication, 32(1), pp.50-61.

- Enos, R.D. and Hersh, E.D., 2015. Party activists as campaign advertisers: The ground campaign as a principal-agent problem. American Political Science Review, 109(2), pp.252-278.

- Foot, K.A. and Schneider, S.M., 2006. Explaining the Adoption of Web Campaigning Practices. MIT press.

- Freelon, D., 2017. Campaigns in control: Analyzing controlled interactivity and message discipline on Facebook. Journal of Information Technology \& Politics, 14(2), pp.168-181.

- Gibson, R. and Ward, S., 2000. An outsider's medium? The European elections and UK party competition on the Internet. British elections \& parties review, 10(1), pp.173-191.

- Gibson, R.K., 2015. Party change, social media and the rise of 'citizen-initiated' campaigning. Party politics, 21(2), pp.183-197.

- Hooghe, M. and Vissers, S., 2008. Websites as a campaign tool for Belgian political parties. A comparison between the 2000 and 2006 local election campaigns. Making a Difference: A Comparative View of the Role of the Internet in Election Politics, Lexington Press, Lanham, MD, pp.171-196.

- Hotham, T. "Brexit and election advertising: an asset for some, a liability for others." Democratic Audit Blog (2020).

- Hotham, T. "'Behind the curtain of the targeting machine": political parties A/B testing in action." UK Election Analysis. The Centre for Comparative Politics and Media Research, 2019. 88-90.

- Kavada, A. 2019. "The movement party-Winning elections and transforming democracy in a digital era: Reflections on Paolo Gerbaudo's chapter." 199-204.

- Krippendorff, K., 2018. Content analysis: An introduction to its methodology. Sage publications.

- Lazarsfeld, P.F., Berelson, B. and Gaudet, H., 1944. The people's choice. Columbia University Press.

- Lee, B. and Campbell, V., 2016. Looking out or turning in? Organizational ramifications of online political posters on Facebook. The International Journal of Press/Politics, 21(3), pp.313-337.

- Lilleker, D., Koc-Michalska, K., Zajac, J. and Michalski, T., 2016. Social media actions and interactions: The role of the Facebook and Twitter during the 2014 European Parliament elections in the 28 EU nations. Routledge.

- Magin, M., Podschuweit, N., Haßler, J. and Russmann, U., 2017. Campaigning in the fourth age of political communication. A multi-method study on the use of Facebook by German and Austrian parties in the 2013 national election campaigns. Information, communication \& society, 20(11), pp.1698-1719.

- Margetts, H.Z., 2001. The cyber party: the causes and consequences of organisational innovation in European political parties. Oxford Internet Institute. 
- Margolis, M., Resnick, D. and Resnick, D.M., 2000. Politics as usual. Sage.

- McDowell-Naylor, Declan. 2019. "\# GE2017: Digital media and the campaigns." Political Communication in Britain. Palgrave Macmillan, Cham 187-205.

- McGregor, S.C., Mourão, R.R. and Molyneux, L., 2017. Twitter as a tool for and object of political and electoral activity: Considering electoral context and variance among actors. Journal of Information Technology \& Politics, 14(2), pp.154-167.

- Metz, M., Kruikemeier, S. and Lecheler, S., 2019. Personalization of politics on Facebook: examining the content and effects of professional, emotional and private self-personalization. Information, Communication \& Society, pp.1-18.

- Neuendorf, K.A., 2002. Message Units and Sampling. The Content Analysis Guidebook. Thousand Oaks, CA: Sage Publications, Inc, pp.71-93.

- Penney, J., 2017. Social media and citizen participation in "official" and "unofficial" electoral promotion: A structural analysis of the 2016 Bernie Sanders digital campaign. Journal of Communication, 67(3), pp.402-423.

- Potthast, M., Kiesel, J., Reinartz, K., Bevendorff, J. and Stein, B., 2017. A stylometric inquiry into hyperpartisan and fake news. arXiv preprint arXiv:1702.05638.

- Putnam, R.D., 2000. Bowling alone: The collapse and revival of American community. Simon and Schuster.

- Rieder, B., 2013, May. Studying Facebook via data extraction: the Netvizz application. In Proceedings of the 5th annual ACM web science conference (pp. 346$355)$.

- Schudson, M., 1998. The good citizen: A history of American civic life. Martin Kessler Books New York.

- Schweitzer, Eva Johanna. "Mediatization in the online election campaign: Findings of a comparative content analysis of German party websites for the election years 2002-2009." The Internet in the election campaign. VS Verlag für Sozialwissenschaften, 2011. 267-296.

- Seidle, F.L., 2004. Expanding the Federal Democratic Reform Agenda. Policy Options, 25, pp.48-53.

- Shephard, M., 2007. Multiple audiences, multiple messages? An exploration of the dynamics between the party, the candidates and the various constituencies. Journal of Elections, Public Opinion and Parties, 17(2), pp.181-201.

- Vaccari, C. and Valeriani, A., 2016. Party campaigners or citizen campaigners? How social media deepen and broaden party-related engagement. The International Journal of Press/Politics, 21(3), pp.294-312.

- Ward, S. and Gibson, R., 2008. European political organizations and the internet: mobilization, participation, and change. Routledge handbook of Internet politics. Routledge, pp.41-55.

- Watts, Jake, and Tim Bale. "Populism as an intra-party phenomenon: The British Labour party under Jeremy Corbyn." The British Journal of Politics and International Relations 21.1 (2019): 99-115.

- Whiteley, P. and Seyd, P., 2003. How to win a landslide by really trying: the effects of local campaigning on voting in the 1997 British general election. Electoral Studies, 22(2), pp.301-324.

- Williams, C. and Gulati, G., 2008. What is a social network worth? Facebook and vote share in the 2008 presidential primaries. Annual Meeting of the American Political Science Association. Citeseer, p.21.

- Zittel, T. and Fuchs, D., 2007. Participatory democracy and political participation. Participatory democracy and political participation. Can participatory engineering bring citizens back in. 